British Art Studies

Issue 18, published 30 November 2020

Cover image: Sonia E. Barrett, Table No. 6, 2013, wood and metal.. Digital image courtesy of Bruno Weiss.

PDF generated on 14 April 2022

Note: British Art Studies is a digital publication and intended to be experienced online and referenced digitally. PDFs are provided for ease of reading offline. Please do not reference the PDF in academic citations: we recommend the use of DOIs (digital object identifiers) provided within the online article. These unique alphanumeric strings identify content and provide a persistent link to a location on the internet. A DOI is guaranteed never to change, so you can use it to link permanently to electronic documents with confidence.

Published by:

Paul Mellon Centre 16 Bedford Square London, WC1B 3JA https://www.paul-mellon-centre.ac.uk

In partnership with:

Yale Center for British Art 1080 Chapel Street New Haven, Connecticut https://britishart.yale.edu

ISSN: 2058-5462

DOI: $10.17658 /$ issn.2058-5462

URL: https://www.britishartstudies.ac.uk

Editorial team: https://www.britishartstudies.ac.uk/about/editorial-team Advisory board: https://www.britishartstudies.ac.uk/about/advisory-board

Produced in the United Kingdom.

\section{Ajoint publication by}




\section{Contents}

The Arts, Environmental Justice, and the Ecological Crisis, Sria Chatterjee 


\section{The Arts, Environmental Justice, and the Ecological Crisis}

Sria Chatterjee

\section{Authors}

Cite as

Sria Chatterjee, "The Arts, Environmental Justice, and the Ecological Crisis", British Art Studies, Issue 18, https://dx.doi.org/10.17658/issn.2058-5462/ issue-18/conversation 
Introduction by

Sria Chatterjee, Institute of Experimental Design and Media, FHNW, Basel and Max-Planck Kunsthistorisches Institut Florenz

\section{The Arts, Environmental Justice, and the Ecological Crisis: A Provocation}

\section{Colonialism/Capitalism}

The history of British art abounds with an interest in the environmental, especially landscape paintings that embody the pastoral and the rural, cloud studies, and stormy skies. John Barrell's Dark Side of the Landscape published forty years ago, convincingly argued that landscape paintings that we interpret almost immediately as idyllic, in fact emerge "from a world of social and economic relations that are anything but idyllic". 1 Writing about Gainsborough and Constable, among others, Barrell's leftist critique of the English pastoral (following E.P. Thompson) urged viewers to see in the harmony that pastoral painting propagated between human and non-human, land and labour, the "evidence of the very conflict it seems to deny". Beyond the English working class, the discipline of art history, especially British art history, is a product of the nineteenth century and thoroughly entangled with histories of colonialism and capitalism-and slavery.

The art critic, John Ruskin's interest in the geological sciences and his mineralogical collection used to teach design aesthetics, architecture, and geology is well known. In Modern Painters (1843-1860), Ruskin pressed artists to study geology. According to Ruskin, landscape possessed "vital truth" by which it simultaneously conveyed the past, the present, and the future. Metal mining in the UK and in the colonies were at its peak when Ruskin was writing. Kathryn Yusoff has recently updated what Ruskin called the "truth of the earth" by showing us how geology (and its fossil objects) is entwined with processes of racialization through speciation and notions of progress, and how it is a mode in which racial logics have been inscribed within the material politics of extraction, continuing to constitute lived forms of racism (from eugenics to environmental racism). Making the link between spatial dispossession of land (for extraction) and dispossessions of persons in chattel slavery (as another form of spatial extraction), Yusoff has argued that geology is historically situated as a transactional zone, in which mineral-asproperty and person-as-property were one and the same. ${ }^{2}$ Conversations with the literary and gender studies scholar Katherine McKittrick have also taught me to think about how a direct line between the race thinking of slavery and our contemporary environmental predicament can end up 
mistreating the complexity of Black time by obscuring Black time. In privileging non-personhood as an origin story, we run the risk of undermining histories of rebellion, multiplicity, and Black life. $\underline{3}$

The Anthropocene is a geological term with deeply political implications. 4 The marking of the Anthropocene has been roundly critiqued for itself being a product of colonial geology, in which spikes are named after a universalizing Anthropos, while the Anthropocene is best viewed as a racial process that has produced and continues to produce racially uneven vulnerability and death. $\frac{5}{}$ Alternative terms such as Capitalocene (coined by Jason Moore) insist that it is not humanity as a homogenous acting unit that can be held responsible for the Anthropocene but accumulation and investment of capital in the fossil economy in certain parts of the Western world that triggered an epochal change. Françoise Vergès" "racial Capitalocene" (following Cedric Robinson) critiques Dipesh Chakrabarty's notion of a universal, undifferentiated humanity that has become a geological force to regard the Anthropocene squarely within colonialism and capitalism's racializing processes. $\frac{6}{}$ The Plantationocene (coined by Anna Tsing and Donna Haraway) mobilizes this concept alongside longer histories of Black, Caribbean, and Indigenous radical thought as well as multispecies ecologies. $\underline{7}$

The British Empire was built on tobacco, sugar, and cotton-tropical crops that could not, at the time, be grown at home. The plantation is a transformative site and process in human and natural history. Visual and environmental histories of plantations expose the structures of power embedded in imperialist, capitalist, and racial formations and the enduring legacy of plantation corporatism that persists today and continues to give rise to modern slavery, growing land dispossession, and accelerated species loss. As Saidiya Hartman has shown, "emancipation" does not in fact end slavery but extends its power through "new forms of bondage" and new modes of thought embedded in our concepts of the human. ${ }^{8}$ Settler colonialism is an unfinished and continuously evolving project and the intimate interrelationships between transatlantic slavery, land grabs, genocide, ecocide, fossil fuel economies, and the financialization of nature continue to shape the global present.

The long and overlapping histories of natural history, slavery, and racism come together illustratively in Britain's museums. The practice of collecting animal and plant specimens that were brought back to England to be studied and later displayed in natural history museums were collected by ship surgeons and captains who worked in the slave trade-often employed by armchair naturalists and collectors who never left London but pried specimens from the farthest reaches of Africa and Latin America (to which 
only slave ships travelled). Once in Britain, plants and seeds from the colonies were often replanted to create hugely profitable plantations in British colonies and formed the fundamental basis of domestic botanical science. Botanists, botanical gardens, and museums became "the base for all economies" and "agents of empire". $\underline{9}$ On the flipside, as Ursula K. Heise has argued, environmental humanities perspectives have sometimes slipped into an essentialist investment in "marginalized" or "local places" as somehow having a more pure, authentic, or real relationship to their geographies than the "Western" or "globalist" perspective. This, however, is a false dichotomy and, as Heise advocates, it is imperative to consider that "both cultural and ecological systems are imbricated in global ones". 10 Nothing, as Tommy Orange writes, "is original, everything comes from something that came before, which was once nothing". 11 British history and art history are similarly blips in longer and complex histories of domination and settlement. The national adjective in British Art Studies is therefore a misnomer in many ways, asking us to critically rethink what national art histories mean in the British or other contexts.

The ecological crisis is, therefore, an intersectional one. 12 The etymological roots of ecology makes us aware of the primacy of relationality, in this case of organisms to one another and to their physical surroundings. The ecological crisis too is an irrefutably relational constellation in which overlapping systems of oppression need to be considered in constant dialogue with the past, present, and future. What does this mean for art historians? The art-historical theoretical toolkit has long separated critical approaches whereby artworks or epochs are studied through feminist critique or Marxist critique or post-colonial theory but rarely applied simultaneously. Does the intersectional nature of the ecological crisis demand a deep transformation in the way art history is structured and taught?

\section{On and Against Representation}

Artists, and, in turn, art historians and critics have at different points paid particular attention to what lies beneath and around them. However, the current ecological crisis has exacerbated the ways in which we pay attention and what we pay attention to. As the artist moves between ethnographer (Foster) to activist (McKee, Demos), what are the stakes of representation and how has the way artists and art historians understand representation changed? 13

The history of British and more broadly Western art has seen natural forms and forces variously as inspiration for technical and emotive representation. For instance, for Edmund Burke, painting was an emotive proxy for that 
which it depicted and John Constable, whose cloud studies were investigations into problems of depth, space, weight, and form, and who diligently read early meteorologists such as Thomas Forster and Luke Howard, saw the sky as an "organ of sentiment". While modernists such as Paul Nash and Henry Moore turned to natural forms and processes as a spur to abstraction, land art in the 1960s and 1970s used the substrate earth-soil, rocks, rivers to create artistic interventions as viewers more aware about their relationships to their earthly environments. Some British land artists such as Hamish Fulton and Richard Long preferred to "take only photographs and leave only footprints", gently critiquing the intrusiveness of land art practices in the United States. The representation of nature-in one form or the other-then has been the primary way artists in the Western world have communed with it. At the same time, pictorial representation has also traditionally served as the vehicle for imperial landscapes and worldviews. $\underline{14}$

The representation of nature as Other, however, is a Euro-American construct. Indigenous Australian paintings, for example, store stories and records of the Dreamings, portraying how the earth came into being, and how the land and its creatures were created and learned to coexist. In other words, they hold an informational structure that makes space for geological and cosmic time-and creates ways of knowing and seeing the world at multiple scales. Even in scholarly endeavours such as post-humanism, where scholars in the Euro-American context work towards a non-anthropocentric worldview, in continuously referring to a foundational ontological split between nature and culture as if it is universal, post-humanist theories erase Indigenous epistemologies. $\underline{15}$

Contemporary artists have approached the ecological crisis in a variety of ways. Some artists such as Olafur Eliasson have opted for grand (carbonconsumptive) gestures in works such as Ice Watch, which transported thirty blocks of glacial ice from Greenland to London's Southbank in 2018. Galleries and public spaces, in the last five years, have been increasingly taken over by artistic projects that try to "represent" the dangers of a warming world and to communicate the effects of rising sea levels, burning forests, and accumulating plastic and toxic waste. Prizes such as the Grantham Art Prize at Imperial College, London commission original works by artists in collaboration with climate researchers with the aim of visualizing and communicating the climate crisis to the broader public. ${ }^{16}$ The geographer Erik Swyngedouw's warning that environmental action has been co-opted by a neoliberalism enthralled by geo-engineering, sustainable innovations, and technological fixes which do nothing to challenge the very conditions that precipitate the ongoing destruction, is one to heed when asking to what ends these means of visualization and representation aim. $\stackrel{17}{1}$ T.J. Demos has argued that the Anthropocene rhetoric, through images and texts, often acts 
as a mechanism of universalization, which obscures the accountability of the military-state-corporation apparatus. It allows instead for a kind of ecocatastrophical aesthetic, which does not speak to the longer systemic capitalist processes and the complex entanglements of corporations, governments, and institutions. $\underline{18}$

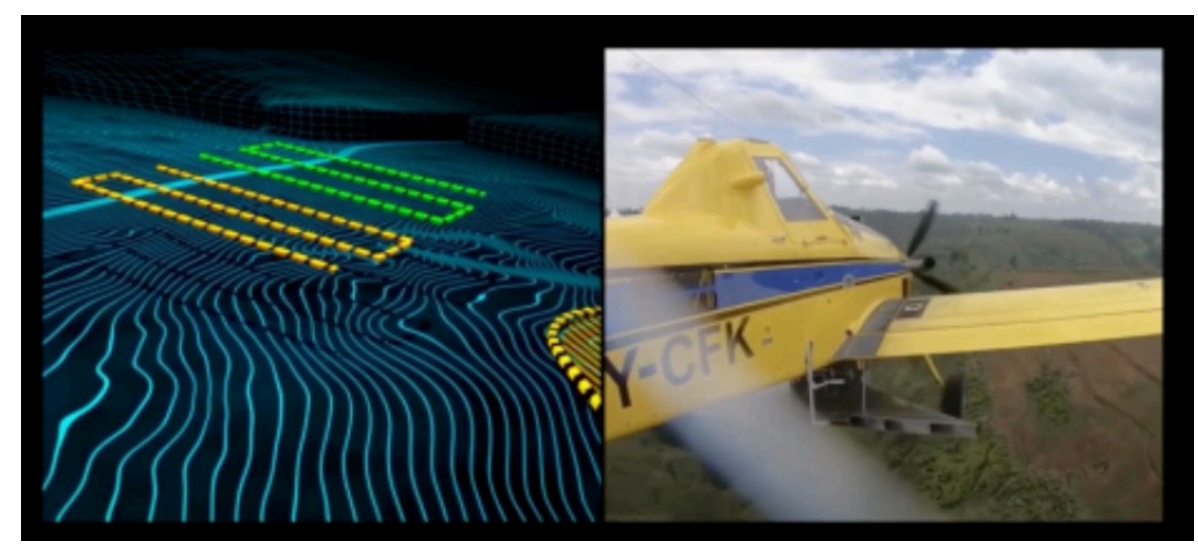

\section{Figure 1.}

Jussi Parikka and Abelardo Gil-Fournier, Seed, Image, Ground, still, 2020, video essay. Digital image courtesy of Jussi Parikka and Abelardo GilFournier (all rights reserved).

Other contemporary artists and designers have opted for research-oriented, forensic practices, which rethink representation to offer tools of resistance, making visible patterns of structural violence and difficult historical trajectories in multispecies contexts that would otherwise go unnoticed. For instance, the London-based group Forensic Architecture's project Ecocide in Indonesia (2017) investigated the 2015 fires in Kalimantan and Sumatra that consumed forests and farmland through fieldwork and satellite image analysis. The results of this investigation established that drainage and "monocropping" by agricultural corporations were direct causes of the fires. Jussi Parikka's Seed, Image, Ground produced in collaboration with Abelardo Gil-Fournier is a visual investigation into the process of seed bombing and links images, seeds, aerial operations, and transformation of earth surfaces into data (Fig. 1). Soil, for instance, from being represented as surface has emerged in artistic practice and theory and criticism as an ecosystem that is alive and implicated in various entanglements, and as an active constituent of the atmosphere. ${ }^{19}$ Artistic research and new strands of interdisciplinary art history that goes beyond eco-criticism have created a space for scholarly and artistic activism for environmental justice. As the field of art history expands and broadens, can art historians critically rethink concepts that are fundamental to art history, such as time and scale, in ways that are productive for an intersectional eco-politics? ${ }^{20}$ Is it time to also question traditional configurations such as "culture" and "design" in a multispecies context? 


\section{Environmental Justice}

Groups such as Art Not Oil, BP or not BP?, UK Tar Sands Network, Platform London, Science Unstained, Shell Out Sounds, and other groups in Norway and parts of Europe have been contesting petro-capitalist corporate power and its long-term hold over public institutions such as museums and universities (Fig. 2). In 2016, Liberate Tate and other London-based groups won a near to six-year campaign, which compelled the Tate to break off its sponsorship agreements with BP. Regardless of this victory, the relationship between museums, the art market, and petro-capitalism is far from over. Platforms such as Culture Declares Emergency include a growing community of artists, institutions, and cultural sector actors who are actively working towards finding ways to use cultural interventions in making transformational change towards the combined catastrophes of climate change, a mass extinction of vital biodiversity, and a degradation of ecosystems everywhere. If "culture" is to play a role in the communication of an ecological crisis, do we have a handle on what "culture" is and what it can be?

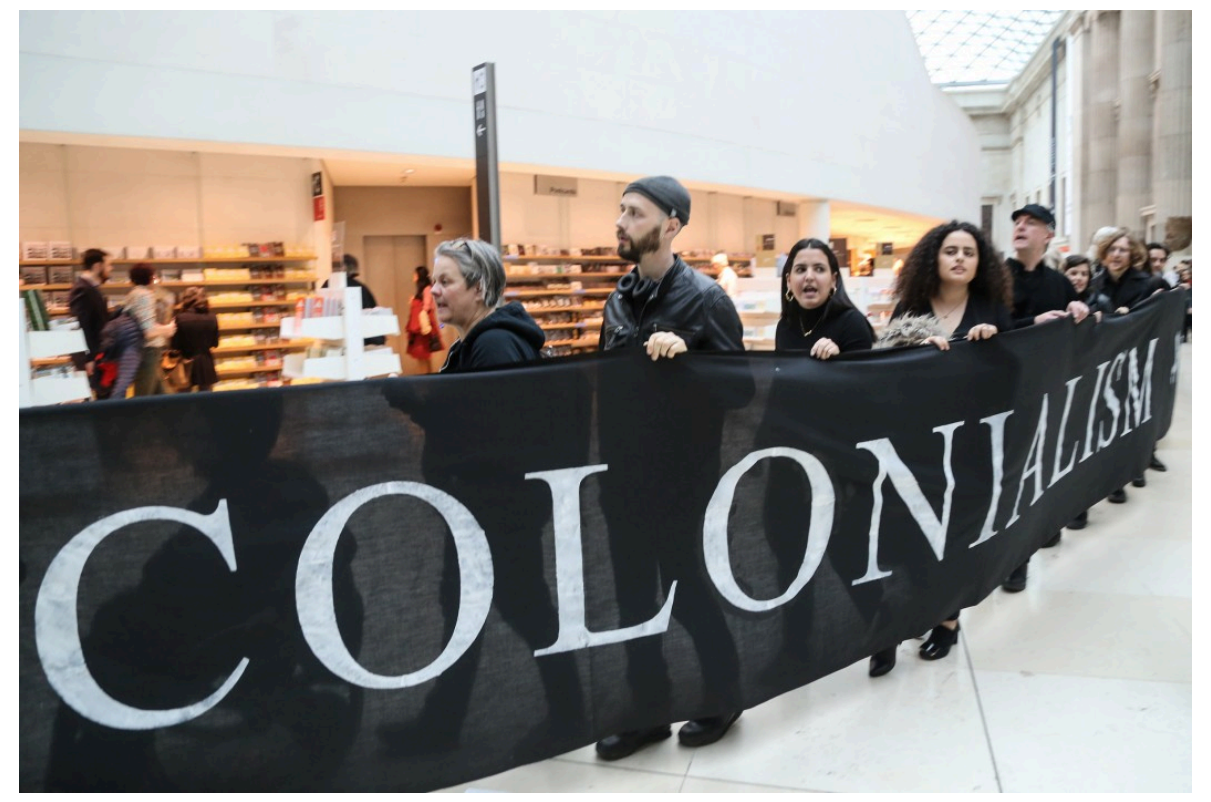

Figure 2.

Diana More, BP or not BP? Statement on the Reopening of the British Museum, 2020, photograph. Digital image courtesy of Diana More (all rights reserved).

What are the next steps? How can artists, art historians, and cultural organizations work together to think and act between theory and practice? What can we learn from other cognate fields such as anthropology, history of science, queer studies, science, and technology studies that allow us to build new methods and practices? 
Response by

Jessica Horton, Associate Professor, Department of Art History, The University of Delaware

\section{Ecocritical Art History for a Palimpsest Planet}

As I read Sria Chatterjee's far-ranging prompt for this forum, several maps flashed before my mind's eye. There was a map created by the Anishinaabe artist Elsa Hoover for the 2016 \#StandingRockSyllabus, which connects the path of the since-completed Dakota Access Pipeline for oil to successive dispossessions of Lakota, Dakota, and Nakota territory in the wake of United States Indian Removal policy; $\underline{21}$ a map of Africa "drooping down like a gigantic question mark" at the Berlin Conference of 1884-1885, where the male leaders of predominantly Western nation-states developed rules for the conquest and extraction of mineral-rich lands; $\underline{22}$ a dual visualization issued by the University College London Institute for Global Health Commission in 2009, which exaggerates nations' landmasses on the one hand, according to carbon emissions (the United States and Western Europe are bloated) and on the other, according to the resulting health effects (now Africa and India loom large); 23 and an altered "map" of the Diné (Navajo) cosmos, a sand painting called Whirling Logs, that the haatali (singer, ceremonial healer) Fred Stevens gifted to the Horniman Museum in London in 1966 in an effort to rebalance a world riven by new extractive technologies and frontiers (Fig. 3). In my imagination, the lines on these maps crossed, merged, and bled, restoring the temporal and spatial heterogeneity, the multiple and often incompatible ways of knowing and relating to the same earth, that colonial maps evacuate. 


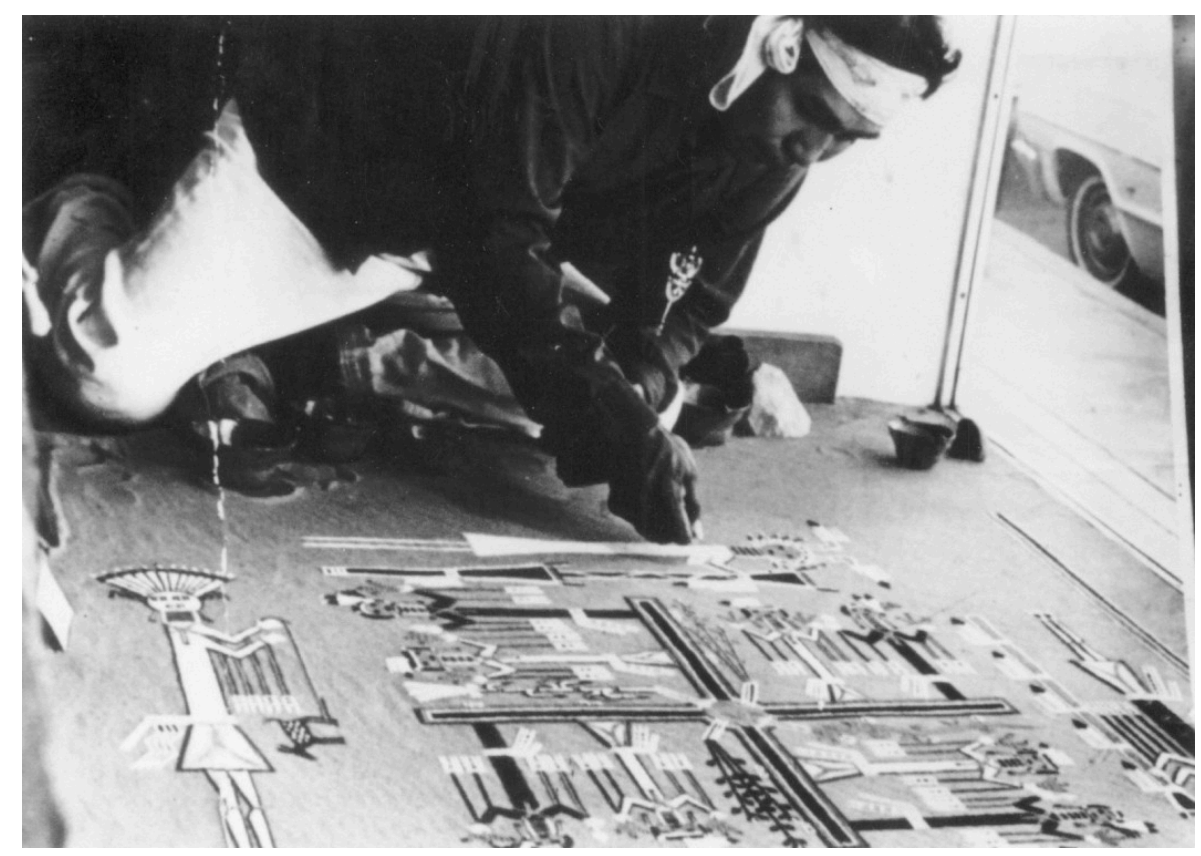

Figure 3.

Fred Stevens creating Whirling Logs at the Horniman Museum, 1966.

Digital image courtesy of Wilmerine Stevens (all rights reserved).

Unlike the blue marble that galvanized hopes for universal peace and holism in 1972, this palimpsest planet is crossed by violent as well as familial relations. A global ecocritical art history adequate to its image must be a collaboration of many who are committed to an expanded intersectionality-one premised on ecological as well as sociopolitical thriving as constitutive of Black and Indigenous justice "alongside the selfdetermination of other communities and societies violently impacted by the white supremacist, colonial, and capitalist logs instantiated in the origins of the Anthropocene". $\frac{24}{2}$ In its infancy, much ecocritical art history has entailed established scholars adapting new methods to familiar objects of study, from landscapes to luxury furniture. It is time to invest in the creative archive of the majority world, reorienting the discipline toward a multiplicity of earth knowledges that are as global in scope as the cosmologies driving the violent expansion of modern nation-states.

Whirling Logs, created during Fred Stevens' US Department of State's sponsored Cold War tour through Eurasian and Latin American countries, is my provocation for such an endeavor. ${ }^{25}$ Stevens mapped a universe of ideal, harmonious relations in the manner taught by the Diné Holy People, the original inhabitants of the earth, by sprinkling colorful pulverized sandstone brought from the Navajo Nation upon a bed of regionally mined sand provided by his hosts. He left the design incomplete to render it safe for circulation beyond Diné ceremonial contexts. $\frac{26}{}$ He then collaborated with Horniman Museum conservators to consolidate the ephemeral work into a 
durable gift. The team reinforced a wooden tray for the work with steel Handy Angle frames and bolts, then used an aerosol gun and a weedol applicator to spray layers of the substrate with Casco Extra-Bond, a polyvinyl glue of Nordic manufacture. $\frac{27}{}$ Whirling Logs was remade as an amalgam of post-war technologies and the earth they were busy upending. It persists in the reconceived World Gallery of the Horniman Museum today, propelling a Diné cosmopolitical mandate to rebalance disordered relations into a precarious future. 
Response by

Ashley Dawson, Professor of English and founder of the Climate Action Lab, The City University of New York

\section{Mapping Fossil Capitalism}

The time to help the public visualize climate chaos is over: the planet is burning, over a million people have died from a pandemic linked to human incursions into the natural world that are simultaneously fueling climate breakdown, and more than a quarter of a billion people face acute hunger as the carbon-spewing global capitalist food system collapses. $\stackrel{28}{2}$ The only people having trouble visualizing climate change at this point are those being paid handsomely for their blindness. If we want to shut down fossil capitalism, if we want to stop hurtling towards planetary ecocide, we have to disarticulate powerful cultural institutions from their alliances with fossil fuel corporations and offshoots such as automobile companies. And we also have to get better at shutting down fossil extraction and its political corollary, fossil fascism. ${ }^{29}$ The art world can help create powerful tools for this struggle.

One way for artists, cultural activists, and researchers to strike against the corporations driving climate chaos would be through a "Mapping Fossil Capitalism" project. Working collaboratively, activists, researchers, and artists could track links between fossil fuel corporations, cultural institutions, think-tanks, and political action committees, among other entities. The fossil fuel industry wants to greenwash its image by promoting itself using corporate sponsorship, but it is not happy when activists indict and publicize these oily ties. In addition to making current fossil capitalist networks visible, such a project could also map the networks of resistance, loosely known as Blockadia. Finally, the project could also map emerging examples of clean energy and energy democracy that provide an antithesis to fossil capitalism. All of this information could be disseminated through cultural institutions, further consolidating public sentiment against fossil capitalism.

There are some strong antecedents for such a mapping project. In their report on oil and gas pollution in Vaca Muerta, for example, the Forensic Architecture group explores the claims of the Indigenous Mapuche people that extraction by companies like Chevron, ExxonMobil, and Total has irreversibly damaged their ancestral homeland in what is one of the world's largest shale deposits. ${ }^{30}$ Taking such forensic work into museums in order to break the ties between cultural institutions and Big Oil, Liberate Tate has executed headline-grabbing and effective actions in museums, BP or Not BP? has challenged the British Museum's ties to Big Oil, and Platform London has 
shown us how to track some of the links between banks, oil, and the arts. $\underline{31}$ In the USA, the photographer Richard Misrach and the architect Kate Orff have collaborated on Petrochemical America, a powerful documentation of the toxic corridor of refineries and chemical industries along the lower Mississippi river. 32

Much of this research and activist work has tended to take the form of institutional critique and disruption, but there are also nascent possibilities to re-articulate cultural institutions in alliance with the forces fighting fossil capitalism. The photograph included here shows a gathering of activists at a ceremony on Ramapough Lenape tribal land in New Jersey (Fig. 4). The pictured totem pole, created by the House of Tears carvers of the Lummi Nation in the Pacific Northwest, had travelled across the USA, knitting together Indigenous communities and their allies in a red line of solidarity against the black snake of fossil capitalism. Bringing activist scientists, curators, and Indigenous water protectors into alliance, the Natural History Museum moved institutions like the Carnegie Museum of Natural History and the Watershed Institute to take a firm stand against fossil capitalism. $\underline{33}$ Mapping and building on these solidarities will be key to the fight to reconfigure cultural institutions into solidarity in the struggle to end ecocide.

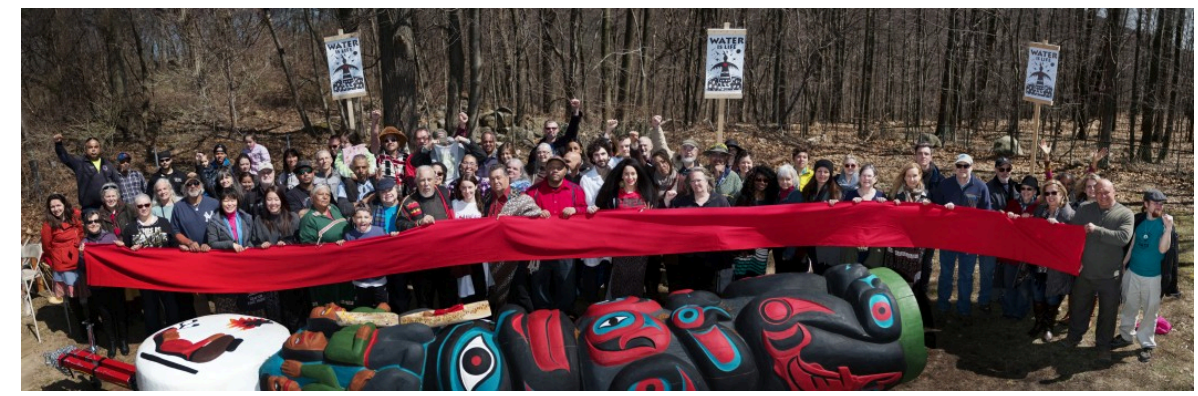

\section{Figure 4.}

Members of the Lummi Nation, the Ramapough Lenape Nation, Science for the People, and the Natural History Museum assemble for a totem pole blessing ceremony on Ramapough Lenape land in New Jersey prior to the opening of Kwel' Hoy: Many Struggles, One Front, an exhibition coproduced by the House of Tears Carvers of the Lummi Nation and the Natural History Museum at the Watershed Institute in Pennington, New Jersey. Dedicated to the sacred obligation to draw the line against fossil fuel developments that threaten our collective future, the Lummi Nation's Totem Pole Journey travels to sites of environmental struggle across the country to build solidarity between communities. Digital image courtesy of Michael Palma / Courtesy of the Natural History Museum, Pennington, New Jersey (all rights reserved).

Lastly, mapping renewable energy will be an important corrective to the danger of kicking off a fresh round of extractivism as the world shifts to energy systems based on renewables. While it is imperative that we transition off fossil fuels, in other words, this change may lead to forms of 
green colonialism whereby minerals and other precious resources are stripped from vulnerable regions in the Global South. $\frac{34}{\text { Even as we }}$ intensify - and win-the struggle against fossil capitalism, we must establish sharp distinctions between genuinely democratic forms of renewable energy that are part of a just transition and new forms of green colonialism and green capitalism. 
Response by

Pablo Mukherjee, Professor of English and Comparative Literary Studies, Warwick University

\section{Lines in the Sand}

Sria Chatterjee concludes her reflections on the arts and environmental justice by asking how artists, art historians, and cultural organisations can communicate the urgency of the contemporary climate crises to their audiences. She also asks what they can learn from "cognate fields such as anthropology, history of science, queer studies, science and technology studies" regarding such communications.

I am, of course, wholly sympathetic to efforts to test out and explore the proliferating modes of production and dissemination of artworks in our late capitalist world. The call for properly interdisciplinary approaches in this context is also entirely appropriate. Still, I wonder whether it might not be possible or even desirable to partially reverse the trajectory of Chatterjee's enquiry and ask instead what the "cognate fields" of professional academia can learn from artists and their responses to climate crises and questions of environmental justice.

Theodor Adorno famously inaugurates his book Aesthetic Theory by declaring that: "It is self-evident that nothing concerning art is self-evident any more, not its inner life, not its relationship to the world, not even its right to exist."

35 Yet, it seems to me from a distance of over half a century, and in no small part because of Adorno's own profound interventions in the debates about aesthetics, we can with some degree of confidence say that what has become "self-evident" over the longue durée of modernity is art's transcendental capacity of generating critical reflections on the historical and social realities that constitute it. That should be enough to settle any doubts regarding its right to exist.

In fact, the Adornian aphorism could easily be adopted in relation to climate crises and calls for environmental justice. As scholars like David Schlosberg have pointed out, the justice movements that took shape in late 1990s North America mostly focused on the issues of the distributional equity of environmental harm and the recognition of the diverse experiences of this harm, but was often blind to its own race and class privileges. Others, such as Neera Jain, have argued that unless calls for distributional, procedural, and recognition justices are grounded in other kinds, such as epistemological, ontological, and cognitive justices, such blind spots will be impossible to remove. Nothing about environmental justice today, to misquote Adorno, is self-evident. 


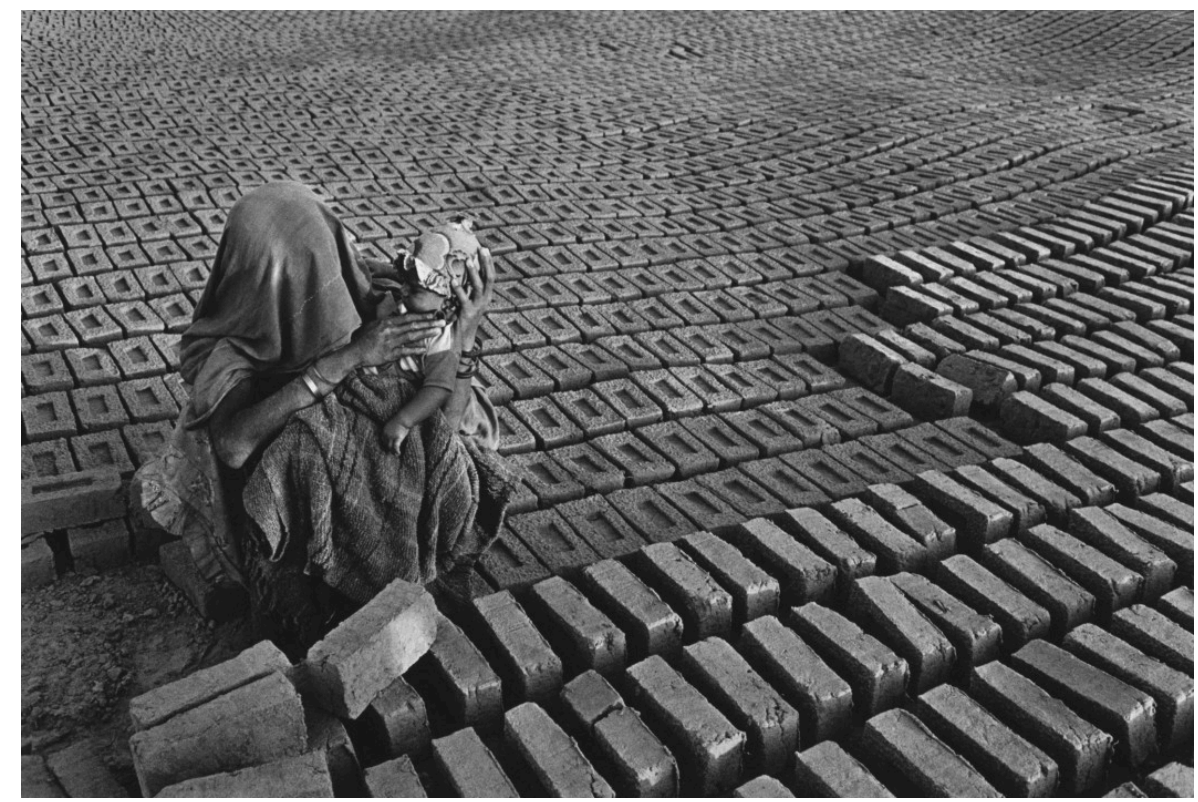

Figure 5.

Sebastião Salgado, Rajasthan Canal Works, India, 1990, gelatin silver print, $30 \times 44.5 \mathrm{~cm}$. The Cleveland Museum of Art (1997.197). Digital image courtesy of (c) Sebastião Salgado / The Cleveland Museum of Art, The Julius L. Greenfield Photography Acquisition Fund (all rights reserved).

My suggestion here is that artwork in the radical modernist tradition-a tradition that has endured despite every effort to "globalise" it-provides an indispensable resource for the operation of environmental justice movements. I want to support this with a necessarily brief and therefore undoubtedly tendentious observation of a single image by the Brazilian photographer Sebastião Salgado from his 1989 series, The Rajasthan Canal Works (Fig. 4). At first glance, this is not in any obvious sense an attempt to document environmental injustice or other kinds. The undulating, mesmerising layout of the bricks seems to raise a visual echo in the pattern on the rough woollen cloth that covers the woman, as well as in the baby's cap. But this virtuoso compositional counterpoint also invites a second glance (and a third, and a fourth...). We are suddenly aware of the interplays not only within the image, but also, for instance, between the image and its title. While the aridity of Rajasthan's desert is captured by the bricks, the rising waves and troughs of their arrangement also recalls the aquatic promise of the canal that is being built with them. But the two human figures on the left foreground immediately raise the question of those sacrificed at the altar of this "development". The arms of the woman cradling the child are scarred and roughened by the exhausting labour at the brick-kiln under the desert sun. Yet, they are also infinitely tender, as if promising the sleeping child, with their touch, a world where water is no longer obtained through the forced appropriation of the life and bodies of impoverished women. No environmental justice today is possible as long as the face of this woman in Salgado's photograph remains unimaginable to us. 
Response by

Shadreck Chirikure, British Academy Global Professor, School of Archaeology, University of Oxford and Professor in Archaeology, University of Cape Town

\section{African Cosmologies and Technologies: The Case of Indigenous African Metallurgy}

Western colonialism and one of its principal drivers-capitalism-were never intended to be benign endeavours. Rather, they were all about selfishness and unrestrained accumulation. Between the seventeenth and late nineteenth centuries, colonialism and capitalism introduced destructive extractivism to regions such as southern Africa. The discovery of diamonds at what became Kimberley in the 1860s brought rapacious capitalist attention to the interior of this area. This was trailed by the significant finding of vast gold deposits on the Rand in what is now Johannesburg in the 1880s. Indigenous groups were forcibly evicted from their land to make way for this resource-extraction-based capitalism and colonialism. $\frac{36}{6}$ Gold mining damaged the environment and utilised toxic chemicals. This polluted water and made mining dumps around Johannesburg's townships in Soweto unsafe and dangerous. $\frac{37}{}$ With no end in sight, a vicious cycle was unleashed: landscapes, hills, valleys, glades, and livelihoods were destroyed-and continue to be destroyed. This was characterised by a dualism: back home, imperial plunderers such as Cecil John Rhodes were hailed as entrepreneurs par excellence, who brought significant wealth home. What were not often told were the ecological, social, and economic crises that had been brought upon the colonies.

Often projected as "the white men's burden", colonialism and capitalism marginalised and ridiculed local people and their knowledge as poor and backward. And yet, most copper, iron, and gold mines worked by early colonialists in regions such as Zimbabwe, South Africa, and elsewhere were sites of Indigenous African metal production. 38 Most famous European explorers actually followed the leads left by African miners and used local informants to identify mineral rich regions. Wrapped up in local cosmologies, Indigenous methods of mining and metalworking were sustainable, ecologically friendly, and produced output with minimal impacts to the environment (Fig. 5). Such mining techniques supplied a major component of the gold circulated in the Indian Ocean system until the 1700s. Other than gold, Indigenous techniques of mining and metallurgy also produced iron which the missionary David Livingstone found, in the late nineteenth century, to be of a better quality than that produced in Europe at the time. $\underline{39}$ Indigenous technologies were banned and assaulted by missionaries and 
colonial administrators while Indigenous cosmologies were attacked for being demonic and barbaric. Capitalism created relationships of dependence whereby Africans had to sell their labour for a living, while helplessly watching the destruction of their environment.

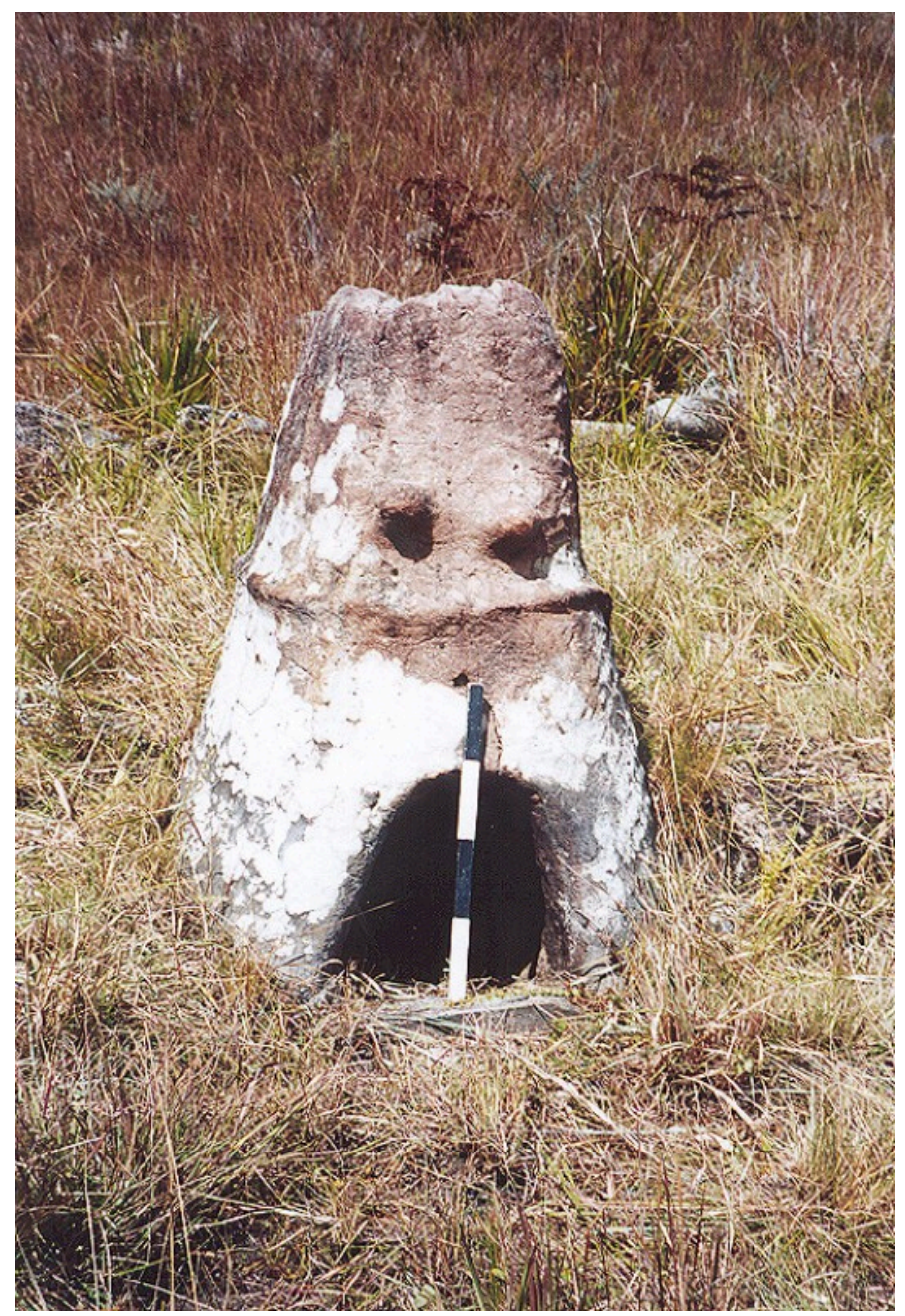

\section{Figure 6.}

Traditional iron smelting furnace used in Nyanga, northeastern Zimbabwe, ca. late nineteenth century. Digital image courtesy of Shadreck Chirikure (all rights reserved).

Meanwhile, the owners of capital continued to accumulate, stockpiling with dire consequences for the environment and its dependent communities. 40 Consequently, the propagandistic talk of sustainable capitalism might be an oxymoron. The big question, however, is: can we introduce Indigenous values and approaches to the environment to arrest the disaster-capitalism-induced ecological crisis? Or is Indigenous knowledge nostalgia that cannot work under the changed circumstances of the present? Trying will tell, but 
Indigenous African cosmologies holistically consider the land and universe as interdependent. Taboos made the land sacred and, in the process, protected the environment and ensured sustainable exploitation of resources.

Archaeology is uniquely positioned to recover some of this knowledge. Remnants of pre-colonial technologies such as metallurgy contain within themselves partial histories of the processes they underwent. Studying them in the laboratory makes such information accessible. Furthermore, studies of sediments permits reconstructions of the impacts of pre-colonial technology on the environment. The results often show that Indigenous mining and metallurgy were neither accompanied by environmental degradation nor toxicity. We need to learn such lessons and strategically reintroduce them, through innovation, into the mainstream for sound environmental and cultural stewardship. The lessons in local cosmologies and attitudes to land, water, flora, and fauna are essential for achieving sustainability. Profit for profit's sake is not civilisation. It is destructive. Its excesses must be resisted. They are the primary cause of the global ecological crisis of our time. 
Response by

Ayesha Hameed, Co-Programme Leader PhD in Visual Cultures, Goldsmiths

\section{Black Atlantis: The Plantationocene}

Black Atlantis: The Plantationocene is the documentation of a live audiovisual essay, or what I call PowerPoint cinema (Fig. 7). It is part of my larger Black Atlantis (2014-present) project, which looks at possible afterlives of the Black Atlantic. It takes as a point of departure, Drexciya, the late twentiethcentury electronic music duo from Detroit, and their creation of a sonic, fictional world. Through liner notes and track titles, Drexciya take the Black Atlantic below the water with their imaginary of an Atlantis comprising former slaves who have adapted to living underwater. This wetness brings to the table a sense of the haptic, the sensory, the bodily, and the epidermal. What below-the-water and Atlantis brings back is the bottom of the sea, the volume of the water, the materiality of the space of the ocean, and other protagonists that inhabit the sea.

View this illustration online

\section{Figure 7.}

Ayesha Hameed, Black Atlantis: The Plantationocene, documentation of a live audio-visual essay, 2020. Commissioned by L'Internationale Online. Digital image courtesy of Digital file courtesy Ayesha Hameed.

Black Atlantis combines two conversations: afrofuturism and the Anthropocene. Its different iterations draw analogies between Mediterranean migration and transatlantic slavery: through temporal leaps into the past and future made possible through afrofuturism; in the foreclosures of futures and the co-mingling of species explored by the Anthropocene; and in the haptic quality of seascapes.

Black Atlantis: The Plantationocene is the third chapter of Black Atlantis. It asks: what is the relationship between climate change and plantation economies, and how might we begin to think of a watery plantationocene? It revolves around two islands: a former plantation in St George's Parish in Barbados and Port of Spain in Trinidad. Visiting the heartland of one of the three stops of the triangular trade, it takes seriously Donna Haraway's and Anna Tsing's use of the term "plantationocene", which connects the development of a plantation form of production to the beginning of the current geological era that we are in.

I draw on my practice as a writer and academic to make work in other media when a linear narrative cannot do justice to the account that I am trying to tell. My work describes current migration and geopolitics through temporal 
shifts into history and into the "not yets" of the future. Because they bring together disparate conversations, my works are necessarily fragmented, or form montages-as lecture performances, sound works, videos, and live audio-visual essays. I incorporate my own audio, video, and writing, combined with other videos and music (which I cite as one would an academic essay), and live readings of diverse works by writers and artists like H.P. Lovecraft, Pete Seeger, Miriam Makeba, Drexciya, and Fred Moten, among others. Each project takes on a different format and, very often, a single project takes on several forms. For example, another chapter of Black Atlantis, Retrograde Futurism (2018), considers the weather as a character in telling the story of the journey of a migrant ship that set sail from Cape Verde to the Canary Islands that was found four months later on the coast of Barbados. It has taken the form of an essay in the catalogue for the Dutch Pavilion of the Venice Biennale of Architecture; it has been performed internationally in the form of a PowerPoint cinema; and it is also included in a video made with Hamedine Kane for Dak'Art 2018 Dakar Biennale of Contemporary African Art. In Black Atlantis, this practice allows me both to look at how landscapes and seascapes act as active characters in large-scale violent migrations, and to find afterlives of the Black Atlantic in contemporary illegalised migration at sea, oceanic environments, and Afrofuturistic dance floors. 
Response by

Macarena Gómez-Barris, Founding Director of the Global South Center and Chairperson of Department of Social Science and Cultural Studies at Pratt Institute

\section{The Colonial Anthropocene at the Sea's Edge}

How do we name the colonial matrix of power at the core of African diasporic and Indigenous dispossessions, or the coloniality that is often unthought within current discourses of the Anthropocene? If The Extractive Zone (2017) focused on territories and land, then my new work orients to the sea and the colonial hauntings that take place at the sea's edge. $\underline{41}$

There is both beauty and terror as we peer from the shoreline, as the film by John Akomfrah, Vertigo Sea (2015), reminds us (Fig. 8). Born in Ghana, in 1957, to anti-colonial activist parents, the London-based artist John Akomfrah was a key founder of the Black Audio Film Collective in 1992, which focused on Black British representation and archival footage by documenting the personal and political experiences of the Black diaspora and other immigration histories.

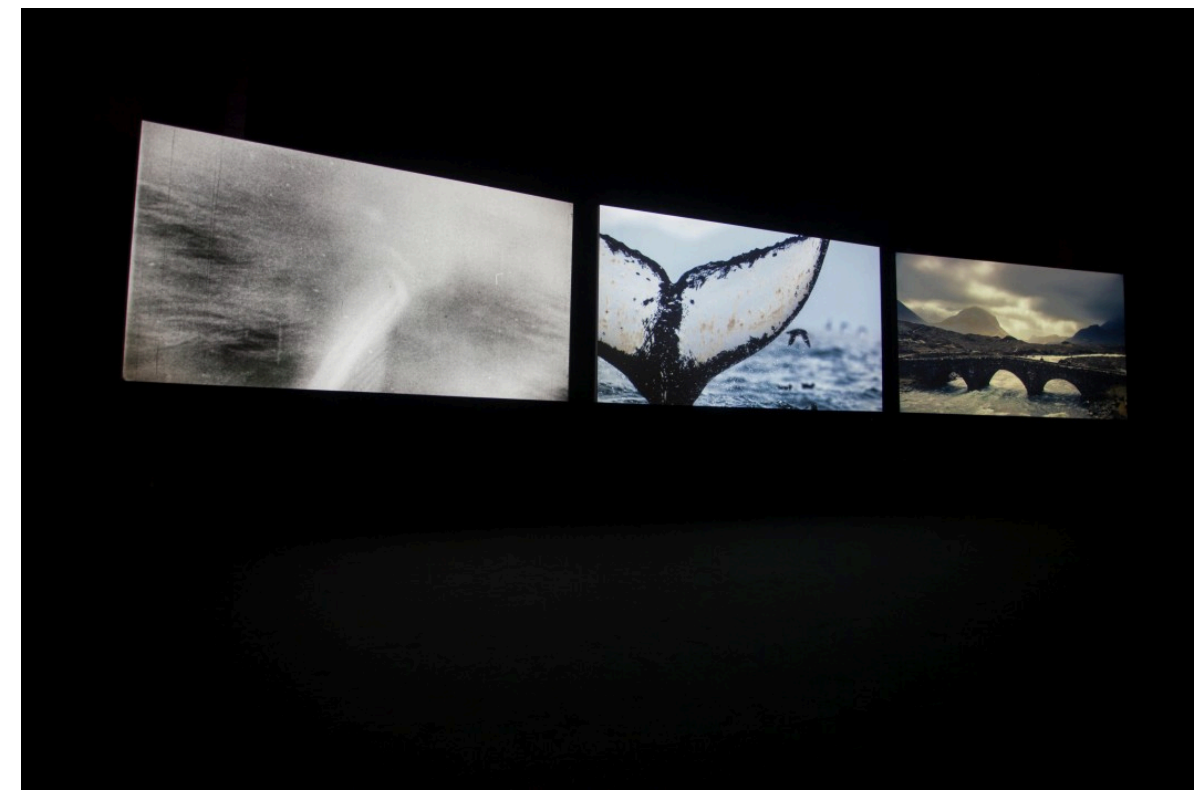

Figure 8.

John Akomfrah, Vertigo Sea, 2015, three channel video installation, screened as part of And the Transformation Reveals, Nuit Blanche festival, Toronto, 2016. Digital image courtesy of Linda Dawn Hammond/ Alamy Live News (all rights reserved). 
Vertigo Sea enters a complex liquid geography, where the ocean is the container, a void, the space of abolition, the site of massacre, and where the history of the non-human is presented alongside the history of racialized humanity's devaluation. The genius of this work is the use of BBC footage from the six-part series Planet Ocean with historical footage of capture-whether it be of whale hunts, or the recreation of the washing up of Black bodies on beaches from the Transatlantic slave trade. This is not about producing histories of equivalence but, instead, makes evident how the archival presence of the sea acts as a visual mediator for colonial and anthropogenic brutality.

The work is a sublime trans-temporal exploration and a visual spectacle that offers a dizzying dive into the ocean as site of history, where images from natural disasters, colonial discoveries, animal massacres, and references to the Middle Passage loop give the audience a submerged view on the terror of coloniality and its ongoing presence in modernity. In one screen, a whale appears with its young. In the prior scene, we witnessed the celebratory black and white footage of whale hunts in the Southern Ocean.

As if to emphasize the disposability of life within the extractive capitalist economic model, Akomfrah also included photographs of General Augusto Pinochet's victims thrown into the sea, recalling Thatcher's complicity in neoliberal dictatorships. In the next scene, a Nigerian migrant describes his terrifying experience of being left adrift in the Mediterranean, alongside a second channel of a lone polar bear floating upon a melting piece of ice. These overlapping palimpsestic images connect global experiences of authoritarianism, expulsion, migration, and extinction to the origin stories of racial and extractive capitalism.

For instance, on the soundtrack, we hear the unsettling words of a haunted past echoing forward as the words of the former slave trader turned abolitionist, Reverend John Newton are re-enacted: "Why do I speak of one child when I have heard of over a hundred men cast into the sea." These words come from the Zong massacre of 1781, where 133 captive peoples were thrown overboard as cargo claims on insurance. Akomfrah makes present a vertiginous claim, the transactional haunt, the sea pregnant with ghostly traces, images, fragments, and echoes within the ebb and flow of the Atlantic Ocean and the Middle Passage.

This aesthetic and decolonial form of connecting across oceans and extractive histories allows us to make present the capitalist imperative of drilling that depends upon moving off the land. We are reminded that, like the ocean, these histories of somatic, earthly and liquid energy return us to the devastating and innumerable capitalist designs of dispossession. 
Response by

Tao Leigh Goffe, Assistant Professor, Literary Theory and Cultural History, Cornell University

\section{Human Resources: Art's History and the Ecology of Black Extraction}

This month, I became inducted into a club that never would have had me as a member; I became a fellow of the Linnean Society. The world's oldest active biological society, founded in $\mathbf{1 7 8 8}$ for the production of natural history by gentlemen in the metropole, for "armchair naturalists and collectors" as art historian Sria Chatterjee aptly describes them. It was established to exclude everything I represent as a Black woman. It is not lost on me that the taxonomy, invented by Swedish botanist Carl Linnaeus and adopted in Europe, is an extension of race as a colonial sorting tool of empire, as Ann Laura Stoler puts it. $\underline{42}$ The taxonomy of race attempted to order and enclose that which could not be bounded, Black life.

The relationship between Black women and research is fraught because we have been the very specimens of taxidermy. I have conducted archival research for the past few years at the Linnean Society (Royal Academy) in London, where I have traced the original letters of white creole traffickers of human, animal, and plant life. The research is for a book I am writing on AfroAsian plantation life titled After Eden. Natural history research is as much reading against the language of the archival grain as it is examining sketches, drawings, and paintings of animals and plants. The visuality of such European colonial archives is striking because it produces another fiction: the underside of the pastoral. Alongside this pictorial taxonomy of non-human life is the accounting and management of Black, Chinese, and Indian life. $\stackrel{43}{ }$ These pictures are not exactly art, but science, not representation, but intended as fact. The violence of the plantation order enclosed my forebears for centuries in the Antilles and tried and failed to erase Indigenous West African and Southern Chinese epistemologies.

I find myself drawn to the aesthetic of artists attuned to these ecologies and cosmologies. I point to an archipelagic aesthetic with the ethos of what the late Barbadian poet Kamau Brathwaite described as "the unity is submarine". 44 Michelle Stephens encourages a vertical axis for examining the archipelago, which I read as the connectivity of global tectonic plates, the geologic bedrock that connects the submarine archipelago. 45 Primary among the artists I identify as of this archipelagic aesthetic is the AfroChinese Cuban painter Wifredo Lam (Fig. 9). He was not the Black Picasso, as

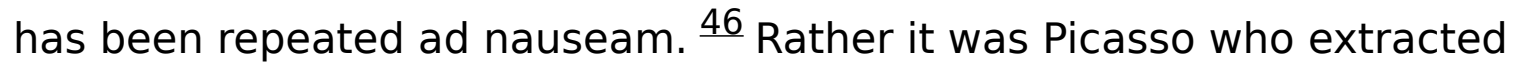
Blackness as a white Spaniard. The photographer Nadia Huggins, another 
artist I identify of this aesthetic, gives subaquatic focus to Indian Bay in the artist's country of birth, St Vincent and the Grenadines. The toponymy suggests the ambiguity of what is sedimented in the geography of the Caribbean (Fig. 10). Is the bay named for the misrecognition of the Amerindian for the East Indian?

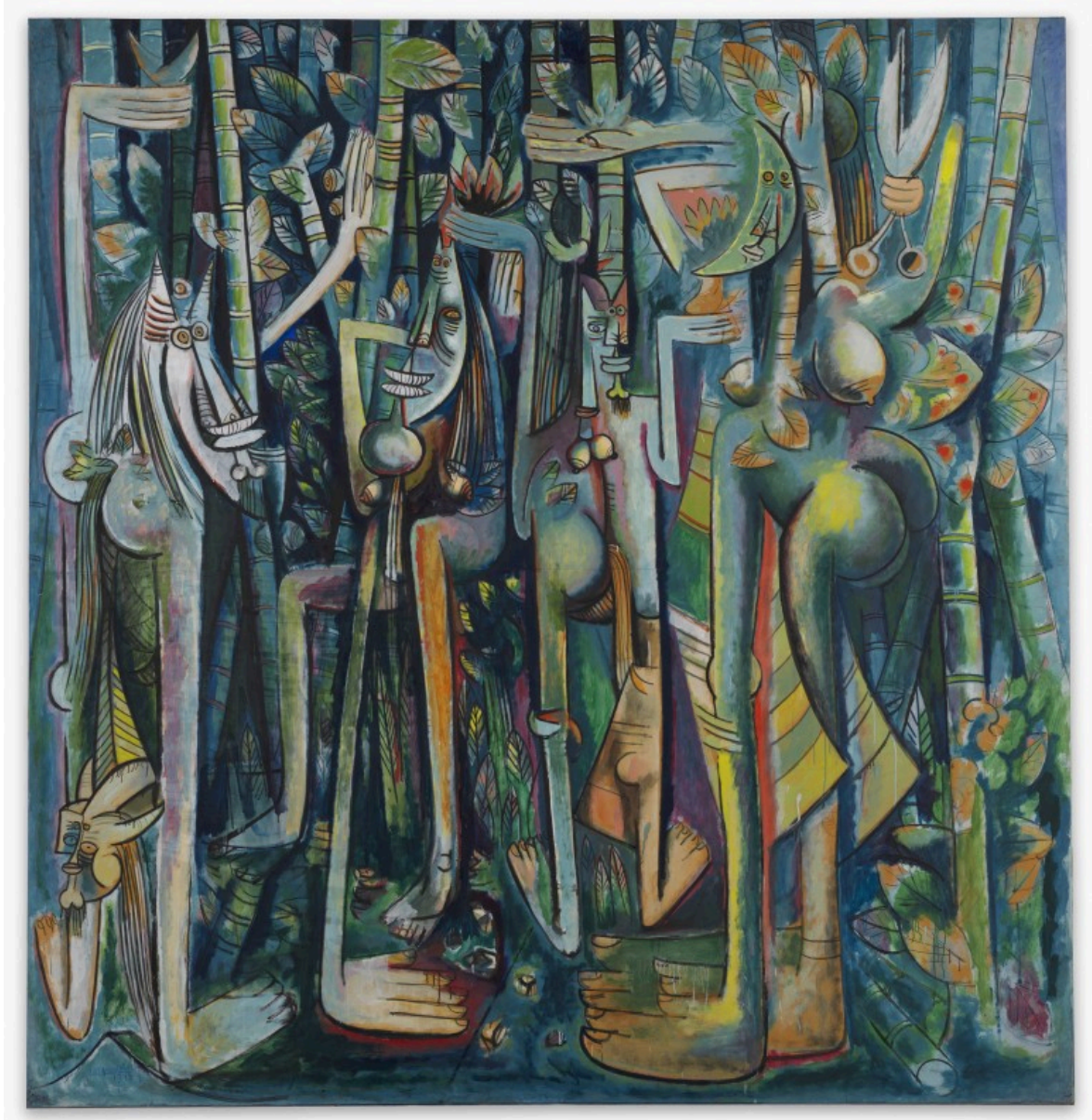

\section{Figure 9.}

Wifredo Lam, The Jungle, 1943, gouache on paper mounted on canvas, 239.4 x $229.9 \mathrm{~cm}$. Collection The Museum of Modern Art New York (140.1945). Digital image courtesy of The Museum of Modern Art New York / Scala, Florence (all rights reserved). 


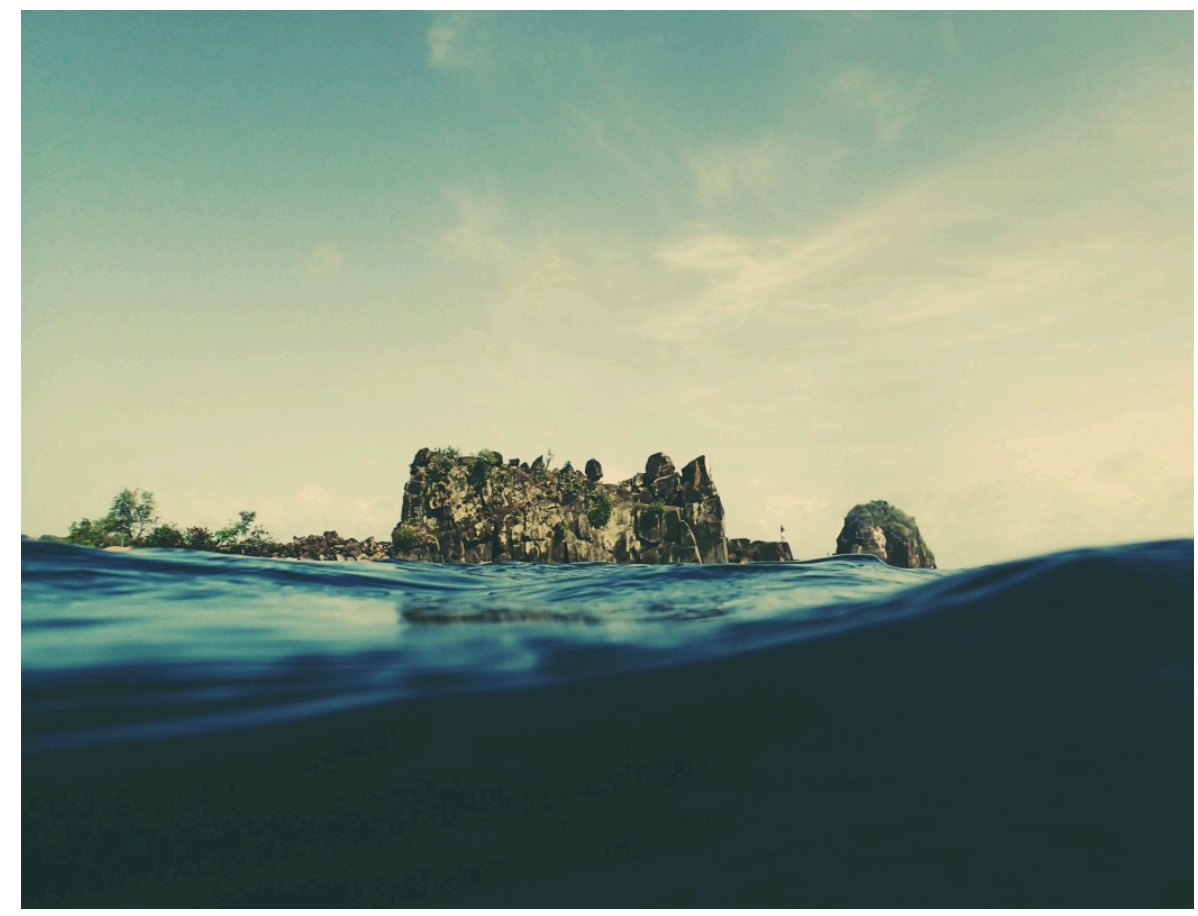

Figure 10.

Nadia Huggins, Circa No Future No. 1, Indian Bay, St Vincent, 2014, photograph. Digital image courtesy of Nadia Huggins (all rights reserved).

I propose a related orientation of analysis to the intersectional art history (following Kimberlé Crenshaw) that Sria Chatterjee suggests, a geological cross section of the ongoing climate crisis. The geological record of sedimented layers of bones, of biomatter, of fossil fuels reveals the uneven violence of human history. Decomposed bones of abducted Africans, murdered Indigenous peoples, and indentured Asians materially and literally compose a bedrock of disposable life, the hemisphere. I have defined this elsewhere as "racial sedimentation" in my examination of the forgotten catastrophe of racial indenture to describe the extractive, transformative, layering of race in landscape. $\underline{47}$

Who is being fossilized or petrified in the ongoing colonial present? The extraction of Black thought operates by the same colonial logic that led to the ecological crisis, capitalism. What are the sedimented layers in the cross section of art history? In the present moment of racial crisis, Black thinkers long ignored are now being drawn upon, extracted for the value of their ideas. Black intellectual capital is acknowledged and synthesized, absorbed by citational practices of extraction. Black thought has become a human resource for the humanities as Black bodies were for the sciences. Where does this situate art history and the citational poetics of representation? When critics synthesize what Sylvia Wynter, Cedric Robinson, and Ruth Wilson Gilmore have been writing for decades about racial capitalism, what sort of intellectual extractivist mining is performed? To mine Black theory 
answers the simultaneous calls to \#CiteBlackWomen and to perform land acknowledgements for local Native tribes. However, citation is by nature an extractive process of intellectual mining that erases even while "saying their names". Citation produces value through appropriation as the logic of capitalist extractivism does. Ultimately, the epistemic crisis adds insult to the injury of the twinned ecocidal, genocidal project of the so-called Industrial Revolution, more aptly the ongoing European Invasion. 
Response by

Giulia Smith, Ruskin School of Art, Oxford University

\section{Lessons from the Eco-Caribbean}

"One meditates here by the Thames-as one meditates there not far from the Amazon or the Orinoco-upon the fate of the earth and its species." 48 Wilson Harris, the Guyanese-born writer and peripatetic intellectual, delivered these prescient words in a BBC Radio 4 broadcast, aired in 1996. I start with his musings on fluvial correspondences because they exemplify a diasporic sensibility capable of intuitively grasping the space-time dislocations of an ecological crisis of planetary proportions. Harris left British Guiana (the country became independent Guyana in 1966) for the imperial metropole at the end of the 1950s, though he continued to travel between Britain and the Caribbean thereafter. Such transoceanic circuits afforded, and continue to afford, a uniquely sophisticated perspective on the Earth's interconnectedness and fragility. Deeply influenced by Indigenous cosmologies (particularly those of the Amerindian communities that, to this day, populate the Guyanese interior), Harris would have recognised the contemporary discourse of the Anthropocene, and the attendant rise of New Materialist philosophies within the North Atlantic humanities, as belated recognitions on behalf of Western intellectuals of the ecological flaws of an imperialist conception of history understood as human progress achieved against the background of a passive Earth.

Although he penned a mesmerising array of eco-poetic texts, inspiring the work of visionary artists ranging from Aubrey Williams to LeRoy Clarke, few scholars (Elizabeth DeLoughrey and Kobena Mercer among them) have placed Harris at the post-colonial core of the ecological critique of modernity. To this day, the humanities continue to privilege what DeLoughrey calls "white (settler) cultural production" over the environmental consciousness of Black, Creole, and Indigenous authors and activists, obscuring a rich tradition of ecocritical thinking with profound insights on the limitations of utilitarian and techno-driven conceptions of progress. Contemporary artists with diasporic affiliations in the transnational Caribbean have been ready to foreground the political and cognitive strategies forged on the racialised frontiers of capital, where the violence of climate change is most harshly felt. For while the biotic exploitation of the Caribbean occupied a central place in the formation of a universally connected market with irreversible anthropogenic effects on the planet, today, this region is disproportionately affected by a global environmental crisis whose local consequences include intensified hurricanes, prolonged droughts, unprecedented floods, dying reefs, and a staggering loss of biodiversity. 
If Harris' generation was primarily concerned with pursuing anti-colonial alternatives to the epistemological and ecological violence of imperial landscape practices, artists practising today are also tasked with giving representation to an unprecedented ecological crisis without divorcing the urgency of this catastrophe from centuries of environmental "slow violence" at the expense of the Global South. In How Flexible Can We Make the Mouth (2019), her exhibition for Dundee Contemporary Arts, the Scottish-Barbadian artist Alberta Whittle used a combination of historic and contemporary imagery to collapse the temporal and ontological distance between the Columbian exchange and the accelerated atmospheric turbulences that now beset the Antilles, and Barbados in particular (Fig. 11). The installation made an affecting case for placing the origins of the Anthropocene with the European colonisation of the Americas, critiquing the universalising geologics implicit in the nomenclature of this discourse. Crucially, the project addressed Britain as a nation founded on collective amnesia, where the historic effacement of overseas regimes of colonial as well as neo-colonial exploitation go hand in hand with the privilege of welcoming each summer heatwave with not so much as an afterthought for the catastrophic ramifications that such climatic anomalies have on a planetary scale.

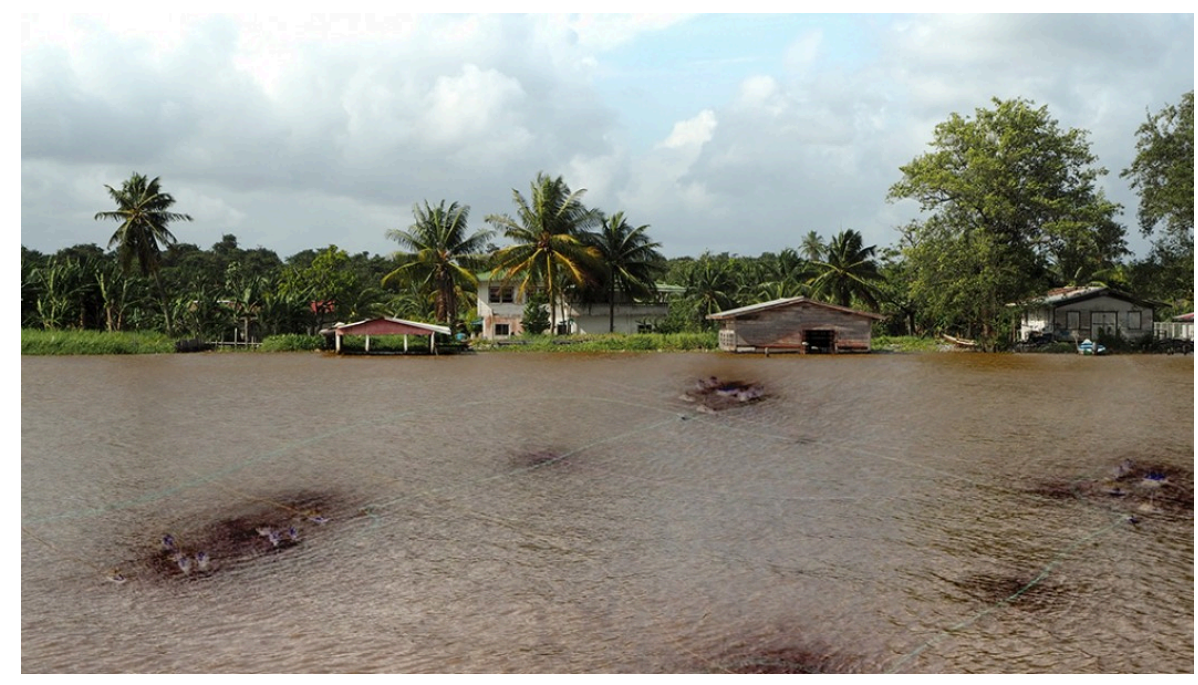

Figure 11.

Roshini Kempadoo, Like Gold Dust, still from the film, 2019-ongoing.

Digital image courtesy of Roshini Kempadoo (all rights reserved). 


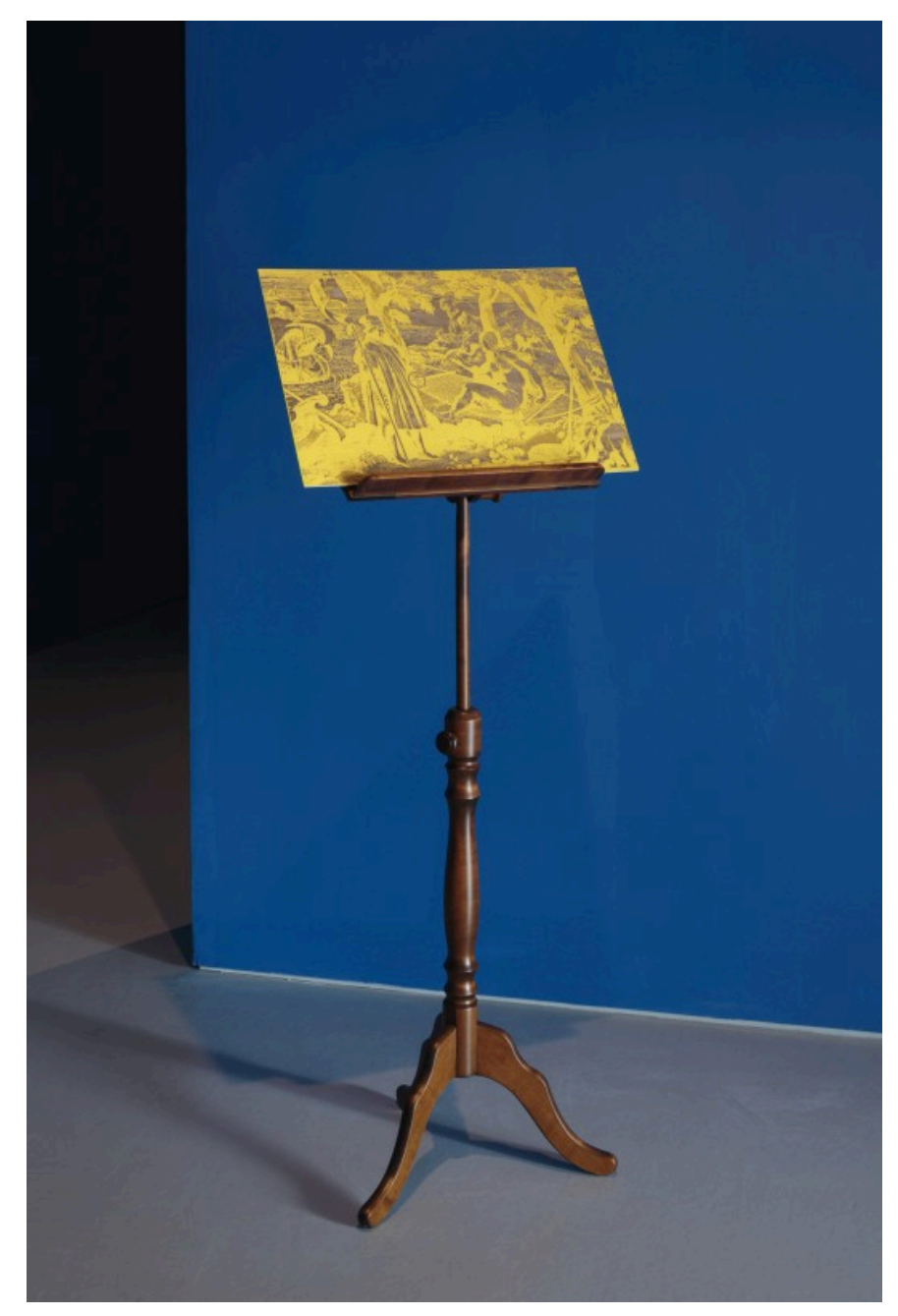

\section{Figure 12.}

Alberta Whittle, Secreting Myths, 2019, installation view from How Flexible Can We Make the Mouth, Dundee Contemporary Arts, 2019. Digital image courtesy of Alberta Whittle / Photo: Ruth Clark (all rights reserved).

Similarly, Like Gold Dust (2019-ongoing) by the London-based artist Roshini Kempandoo ventriloquises and amplifies the environmental activism of Latina and Indigenous women in the Americas, drawing on the work of Kathryn Yusoff to link histories of mineral extraction with centuries of Black subjection (Fig. 12). The daughter of Guyanese parents, Kempandoo conceived this multimedia project as a fictional dialogue between two activists based respectively in Texas and Guyana, two countries connected by an unevenly shared fossil fuel economy (ExxonMobil, the Texan oil and gas corporation, effectively holds a monopoly over Guyana's recently discovered crude reserves). Like Gold Dust complicates official narratives about the benefits of foreign investment in the Guyanese economy by foregrounding the perspectives of those women who are simultaneously at the forefront of protests against neocolonial extractivist ventures and at the 
sharp end of their cataclysmic effects on the planet, but whose voices go largely unheeded in the West. This erasure further speaks to the universalising operations that characterise Western approaches to environmentalist thought. In stark contrast, Wilson Harris always maintained that post-colonial societies in the southern hemisphere of the world possessed the "genius to tilt the field of civilization", so that one may reach "a different apprehension of reality", and begin to address the future in radically inventive and progressive terms. ${ }^{49}$ This tilting, I want to suggest, is what art historians should champion in the face of today's crises. Indeed, the discipline has much to learn from the decentred, transhistorical, and polyvocal imagination of artists like Kempandoo and Whittle. 
Response by

Andil Gosine, Professor of Environmental Arts and Justice, York University

\section{"Very Mongoose"}

"I feel very mongoose these days", Kelly Sinnapah Mary says from her studio in Saint François, Guadeloupe. This year the artist has created many drawings and paintings that respond to two dominant concerns of 2020, the COVID-19 pandemic and police violence against Black people. A range of cartoonish animal and hybrid figures, such as the self-representational threetailed mongoose wearing her elementary school shoes, appear in these works (Fig. 13). They are an expression, in part, of how feelings of distress and an awareness of her own visceral animality, including her survivalist instinct, are amplified in times of crisis. Sinnapah Mary's imagined figure in this painting also has a basis in colonial history. The Javan mongoose was introduced to the Caribbean in the 1870s as a form of pest control for snakes and rats in sugarcane fields. The method was effective but the predators also exterminated several indigenous species in the process. 


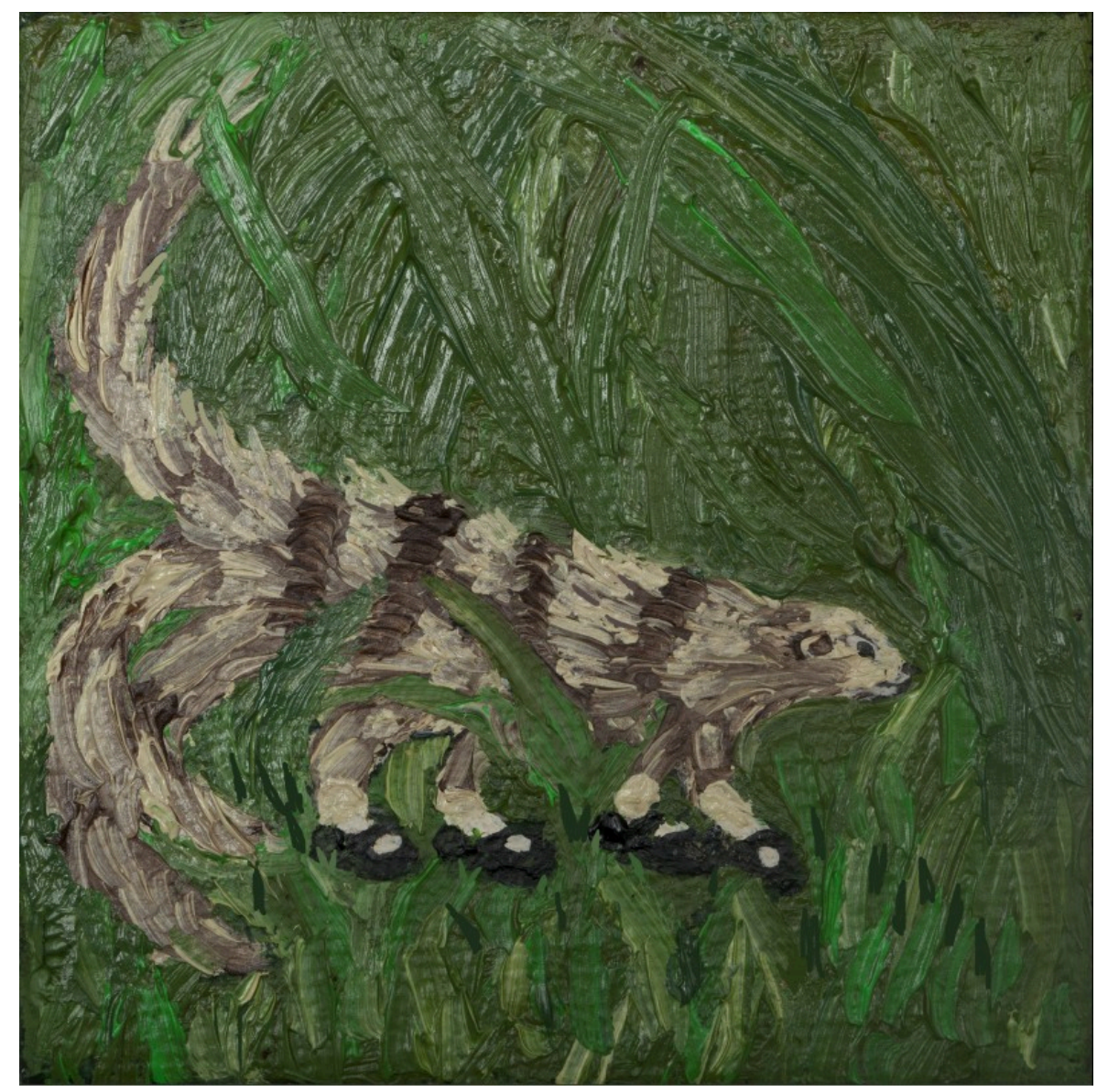

Figure 13.

Kelly Sinnapah Mary, The Three-Tailed Mongoose, 2020, oil on canvas, 7 x $7 \mathrm{~cm}$. Digital image courtesy of Kelly Sinnapah Mary (all rights reserved).

In my upcoming monograph Nature's Wild: Love, Sex, and Law in the Caribbean, I write about a previous series of Sinnapah Mary's works, which similarly trouble the line set between human and non-human life. This differentiation was foundational to colonization of the Americas, justifying the conquest of nature and, simultaneously, non-white peoples. Indigenous and enslaved peoples and indentured workers, who were brought to the western hemisphere following emancipation, were placed somewhere between the poles. They were "less human, more animal", and therefore deserving of both the oppressive extraction of their labour, akin to the extraction of natural resources, and candidates for the civilizing hand of colonial powers. The potency of this logic is still felt 500 years after Columbus's arrival, including through laws that govern sexuality (sodomy and bestiality are usually linked) and norms around dress (humans wear clothes, animals are naked). Beyond the Caribbean, the near-universal effort that we expend in most human societies to define ourselves as human-not-animal has the 
effect of disciplining measures, which tend to be more punitive to humans who less fit defined norms of humanity. It also works against experiencing empathy for and allyship with non-human animals.

In the context of urgent environmental crises, including accelerated species extinction, artistic endeavours like Sinnapah Mary's provide a unique service to the project of environmental justice. None of her works illustrate a specific environmental disaster, nor do they shout a fix for one or even offer an aspirational slogan. Instead, what her practice does is represent some of the complex terrain of the broad historical trajectories and processes, including our unconscious and subconscious impulses, which produce conditions of the present. Some visual artists have and will continue to work with environmentalists to design images with clearly defined messages that speak to specific issues of justice. But there is a place too-a much more interesting one, I think-for the kind of work accomplished by Sinnapah Mary's practice. Both for herself and her audiences, she probes our location in this crisis, asking us to consider how our experiences of trauma and injury inform the understanding we have of our place in nature, and to reflect about how we might be implicated in its destruction. 
Response by

Franklin Ginn, Senior Lecturer, School of Geographical Sciences, University of Bristol

\section{The Trouble with Relationality}

Any art which responds to nature, creatures, the land, or the environment must now grapple with the planetary axes described by Sria Chatterjee-the epoch's "white geology", as well as its creatively destructive capital flows that remake landscapes and mould human psyches. $\stackrel{50}{ }$ We live in times in which relationality seems to be the name of the game at all scales: from biogeo planetary processes, to the warp and weft of deep time as it emerges in the present, to knots of creatures implicated in mutual becoming and living.

Artistic responses, as Sria Chatterjee notes, increasingly embody an activist sensibility, a thirst for eco-justice, and a desire to repair past violence. The ethical and political impulse here is twofold. First, to witness creatively anthropocenic relationality and so dent collective myths of invulnerability and mastery. Second, to weave new relations of care for progressive ends. Anthropocenic art is based upon a wager on relationality.

I suggest, however, that relationality is more uncertain ground than it seems for anthropocenic art and environmental justice. The initial and most obvious reason is that the ontological reality of being-in-relation does not map on to a given set of ethico-political outcomes. Beings can be brought into relation through noticing/care/love as well as through exploitation/violence/ death-and often through both vectors at once. Relationality is fertile ground for projects of settler-capitalist exploitation, as well as progressive projects of care.

Multispecies relationality is tricky - we may care, but our non-human others usually do not. Who makes planetary life possible? The green ones, our photosynthesising companions; those who transmute the sun's energies into the stuff of life and have done so for two billion years. Yet, they remain profoundly indifferent to us. We may be brought together on our plates, in the forest, in the palm oil plantation, but the plant remains profoundly other and uncaring. There is a relationality here, but it cannot cross easily into generalised multispecies ethic of care. ${ }^{51}$ While most obvious when looking at plants, all creatures are subtended by this one-way "relation to an unreadable other", as Clare Colebrook puts it. ${ }^{52}$ Alterity and distance are the necessary supplement for life and relation. 
This asymmetry works on other scales, too. The processes of geology and atmosphere are not, despite the fantasies of the geo-engineers, manageable. As the geographer Nigel Clark continues to argue, the earth persists through abyssal forces that cannot be cared for, only endured. $\underline{53}$

Art should be well placed to face these asymmetries. An anthropocenic art ethic might tack less towards composing new relations of care and more towards evoking the ineffable, the alien, and the ungovernable parts of planetary. Not through communicating, meaning-making, or activism within the contours of "the actual", but also by opening our senses to a larger set of realities. 
Response by

Sonny Assu, Artist

\section{LAND BACK! Digital Posters as an Archive of the Movement}

Before the 'Rona. Before the "murder hornets." Before the murders of Black, Indigenous People of Colour (BIPOC). Before incompetent and privileged white men stole power from the people (actually, that's been going on since time immemorial). Basically, before 2020 became a complete and utter dumpster fire, Indigenous youth across what is now known as Canada stepped up to protect the Land and Water against a natural gas pipeline expansion that would cut across the traditional territory of the Wet'suwet'en.

In an era of United Nations Declaration on the Rights of Indigenous Peoples (UNDRIP), quote-unquote-reconciliation and Canada's PM stating there is nothing more important than the relationship between the settler state and Indigenous peoples, this pipeline was a slap in the face-not only to Indigenous people but the environment we all take for granted.

In January, the government decided it was time to get the Coastal GasLink project underway. Proposed a decade earlier, this pipeline would carry natural gas from north-eastern British Columbia (BC) through unceded Wet'suwet'en territory (in the north-western, central interior of the province) to the fragile coastal waters near Kitimat to be liquefied and shipped to markets in Asia. Although approved by the twenty First Nation band councils (imposed through the Indian Act) along the route, the hereditary leadership of the Wet'suwet'en people stood in defence of the environment. The Wet'suwet'en believe it is their hereditary duty to defend the environment for the benefit of all. The hereditary leadership issued a call to action, and Indigenous people across the country came together in a beautiful way. Warmed by the sacred fires, they said "NO" to the powers that be. They continue to say no because the Land was never ceded, sold, or transferred. They erected blockades to keep heavy equipment from pouring in, and they issued an order that the Royal Canadian Mounted Police (RCMP) must leave their territory. Activists flocked to the frontlines to add their support. Drums, songs, dances, and traditional language blended with the smoke of the sacred fires to let the ancestors know their ultimate goal: Land Back!

Indigenous people and their allies, from every walk of life, held rallies and demonstrations across the country. Shutting down vital intersections, railways, ports, and occupied government buildings. Beyond Land Back, they demanded respect and they wanted to hold the governments accountable for their actions and inactions. But most importantly, they wanted the powers that be to listen to the original people of the Land. As the weeks rolled by, 
tensions between Indigenous folk and settlers grew. The benign image of the tolerant and just Canadian has worn thin on the international stage as the colonial state's systematic racism has started to shine through. It was the dead of winter in BC's snow-encrusted Northern region, and the Land defenders on the front lines were beginning to face-off against Canada's national police force. Heavily armed RCMP officers were sent in to clear the way for the pipeline work.

As an artist, I like to use my platform to elevate conversations. As an Indigenous person, I feel it is my duty to protect the Land and the Water, to preserve it for our future ancestors. And this is where my two realities meet. Not all my work is political ... but there are traces of politics in everything I make. Now, these pieces-designed as posters-are overtly political (Figs 14-16). They slap you in the face a bit with it, frankly. They are a call to action, and an archive of the movement. 


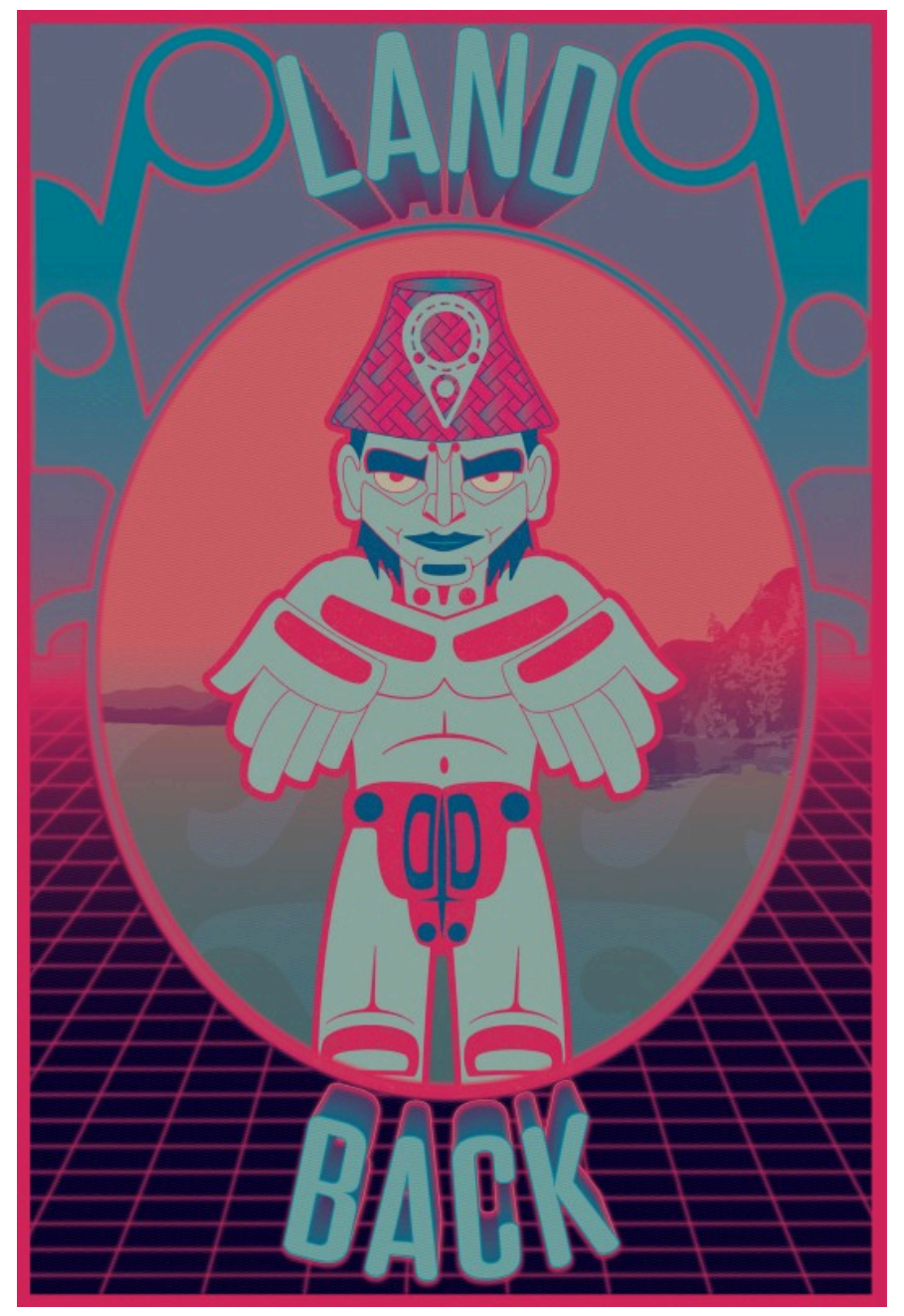

Figure 14.

Sonny Assu, Land Back, 2020, digital image, 24.5 x 36.5 in. Originally produced for CONVERSATIONS Langue et Propagande / Language and Propaganda (The Publishing Eye, 2020). Digital image courtesy of Sonny Assu (all rights reserved). 


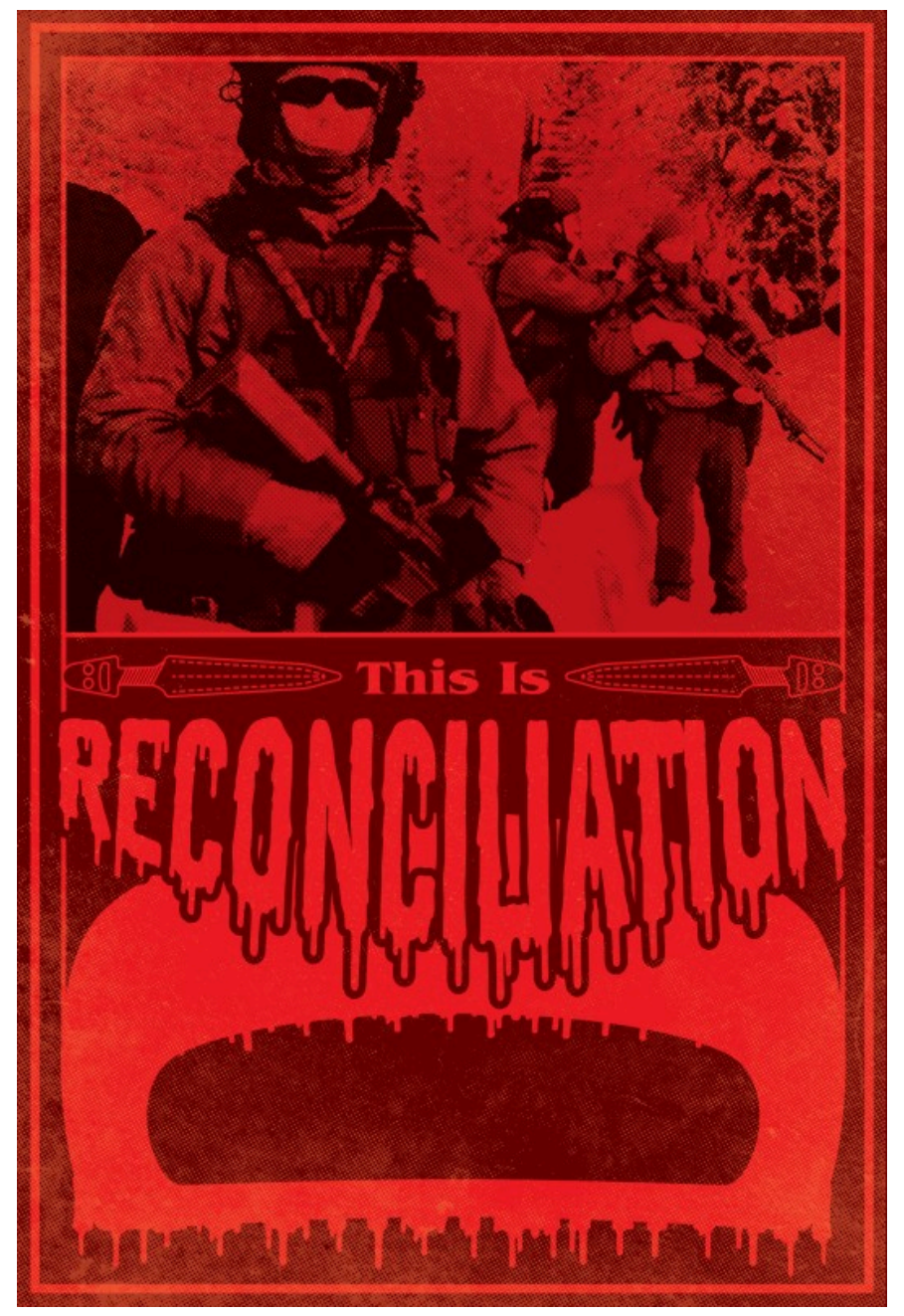

\section{Figure 15.}

Sonny Assu, This is Reconciliation, 2020, digital image, $24.5 \times 36.5$ in. Originally produced for CONVERSATIONS Langue et Propagande / Language and Propaganda (The Publishing Eye, 2020). Digital image courtesy of Sonny Assu (all rights reserved). 


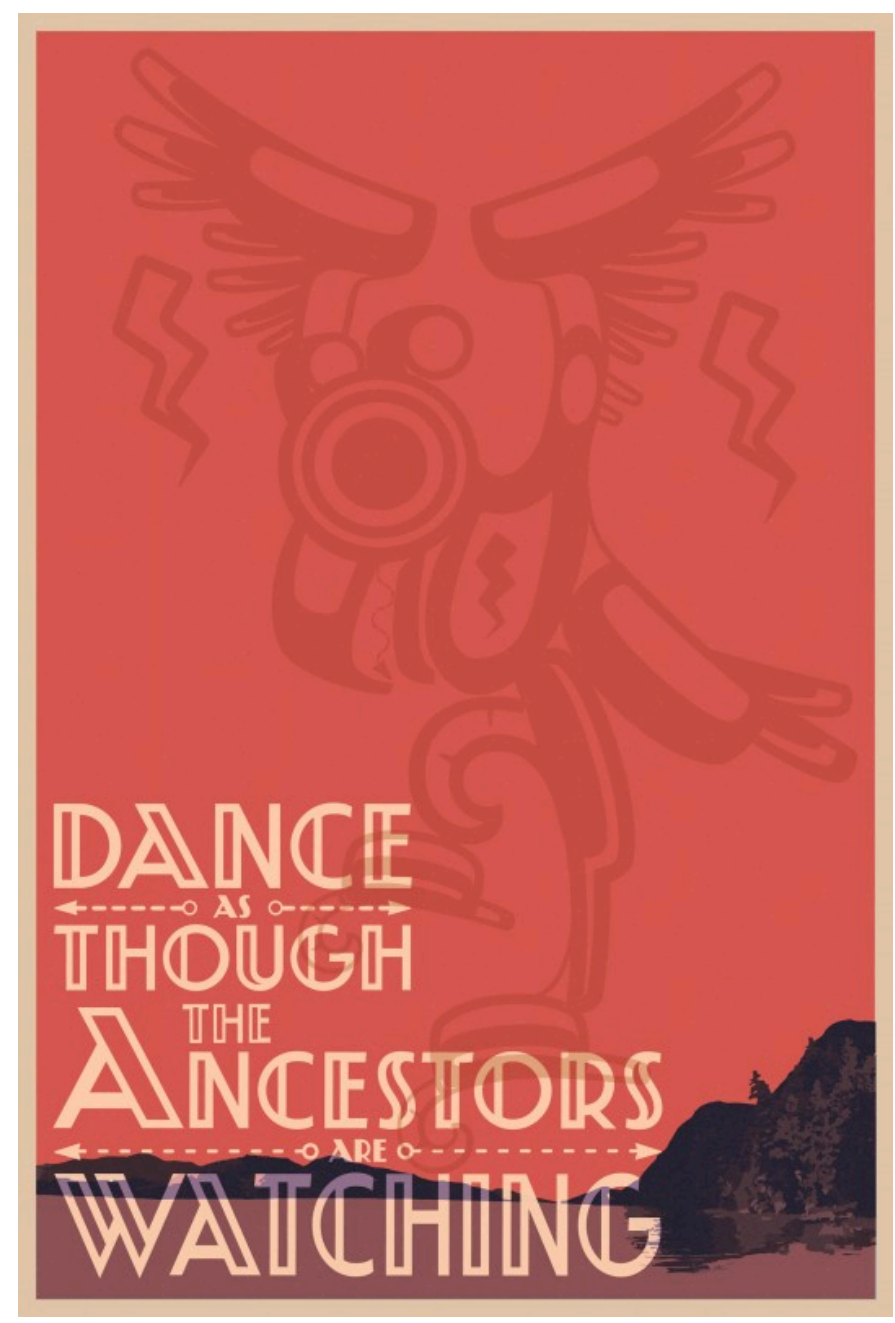

\section{Figure 16.}

Sonny Assu, Dance as Though the Ancestors are Watching, 2020, digital image, $24.5 \times 36.5$ in. Originally produced for CONVERSATIONS Langue et Propagande / Language and Propaganda (The Publishing Eye, 2020). Digital image courtesy of Sonny Assu (all rights reserved).

As we reflect on this dumpster fire of a year, COVID-19, murder hornets and climate change: we can look back to the settler-colonizer ancestors and lay the blame directly at their feet.

I've been immensely impressed by the current generation of Indigenous Land/Water defenders. Some, having been raised on the frontlines, are coleading this current movement. They have stood up to recognize the farce of reconciliation (some say it's dead, I ask if it was ever alive) and have demanded Land Back because they carry themselves, as they know their ancestors are watching. 
Response by

Douglas Kahn, Professor Emeritus at University of California at Davis and University of New South Wales, Sydney

\section{Generating}

The best-known golden spike was never meant to stay where it was. Leland Stanford drove it into the ground to ceremoniously tie together the First Transcontinental Railroad: "May God continue the unity of our Country, as this Railroad unites the two great Oceans of the world" (Fig. 17). With its inscription and silver hammer scratches, it is now on view at the Cantor Arts Center at his university, one of those treasures that, according to Walter Benjamin, documents barbarism that one "cannot contemplate without horror". $\underline{54}$ When the golden spike travels on loan, an official replica takes its place-both put Native American genocide on display.

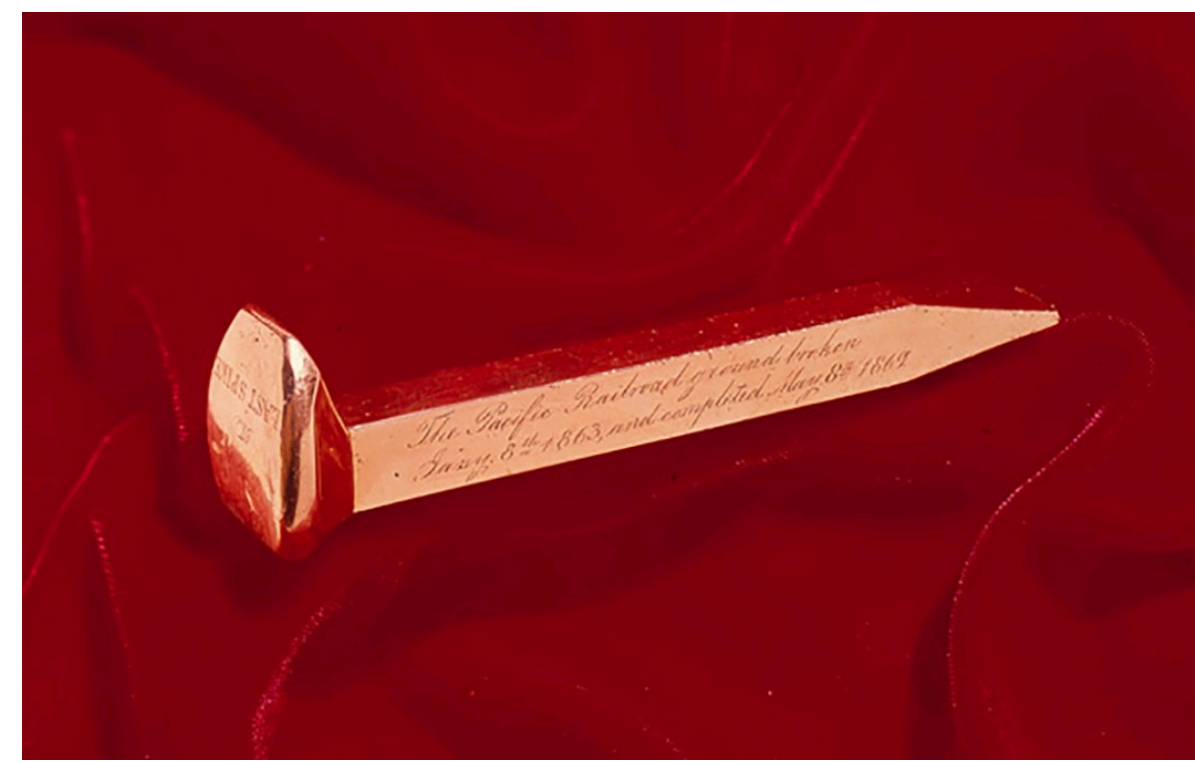

\section{Figure 17.}

William T. Garrett Foundry, The Last Spike (The Golden Spike), 1869, gold, alloyed with copper, $1.11 \times 14.13 \times 1.27 \mathrm{~cm}$. Collection Cantor Arts Center, Stanford University (1998.115). Digital image courtesy of Cantor Arts Center, Stanford University, Gift of David Hewes (all rights reserved).

The golden spikes of the Global Stratotype Section and Point variety were virtually unknown outside stratigraphy prior to the Anthropocene discourse boom. Their value lies in remaining where they are, implanted in geological strata as an emblematic marker corresponding to a particular passage of time at all points on earth. To establish a GSSP for the Anthropocene, stratigraphers contemplated the genocide of 50 million Indigenous Americans and the isotopic signature deposited by rehearsals for global 
nuclear annihilation. Deracinating mass death to create a tool betrays a note of optimism: geologists showed care far off into the future for their professional progeny, whether they will exist or not. Those preferring to read histories in ice cores are less sanguine.

That geology became a touchstone discourse in the epoch of climate catastrophe was bizarre given its dominant professional focus. Awkwardly announcing that 2019 would be the Year of Carbon, the British Geological Society stated that: "Carbon-based energy resources [...] remain of critical importance as both a source of energy but also in planning for a future carbon-neutral society", filtering emissions from its journal Petroleum Geoscience. $\frac{55}{1}$ It was irksome to see geologists who trained extractors, if not worked directly in the industries themselves, schooling arts and humanities events over the last decade.

Universities need to extract themselves from these fruits of the profession, not just financially. That Yale, the university associated with this journal, is still defending its fossil fuelled portfolio as recently as February 2020 should be contemplated with horror. $\underline{56}$ Geologists fantasize about providing future generations of geologists with tools of deracinated death, but Yale has decided to amortize (OED: stem amortir, to die, become lifeless, to kill, destroy...) their progeny, although contributing to global heating is certainly one way to decrease legacy admissions.

When too fixed towards the past, art history-unlike climate modelling-can be rendered inept among the latencies between actions and their consequences, surrendering an ethics of intergenerational care and justice. Setting aside how the discipline might tie time together, here is one artistic moment at the Edinburgh Festival during the mid-1980s. A young Polly Higgins sees the work of the artist, architect, and environmentalist Hundertwasser and: "He really inspired me ... and as a result I ended up spending time with him in Vienna and learning an awful lot about the European ecology movement". $\underline{57}$ Higgins would become a barrister and the driving force in attempts to get ecocide recognized internationally on a par with war crimes and genocide. The recent development of climate attribution studies means that corporate, state, and individual actors can now be better identified in civil suits for what they hide in latency, in time, and for the crime of ecocide, should it be officially recognized. $\underline{58}$ The question is whether enough time is left for the law. 
Response by

Andrea Gaynor, Associate Professor of History, The University of Western Australia

\section{The Making of Collins Street}

Art-not least British settler colonial art-has proven a fertile field for the practice of environmental history. Topographical and landscape artists, in particular, included a wealth of ecological and climate information in their works, which-even accounting for stylistic distortions-yield valuable information about past environments, as well as environmental perception. For example, Bill Gammage used colonial artworks as compelling evidence for particular forms of Aboriginal land management in The Biggest Estate on Earth (2012). Ian McLean and I also created a database of art from the Swan River region of Western Australia that showed how artworks collectively over time depicted fewer trees of large girth, and less local flora, over the period from 1827 to $1950 . \underline{59}$

This is useful work, but the time has come for environmental historians to move beyond art that makes "landscape", "nature", or "the environment"-intentionally or otherwise-a principal subject. In a planetary system, environment is omnipresent; the question is therefore not whether an artwork has environmental content, but rather the form and degree of transformation of the non-human world that is depicted: the less "nature" we see, the more it has been transformed, and the more we should wonder about how it came to be that way. 60 


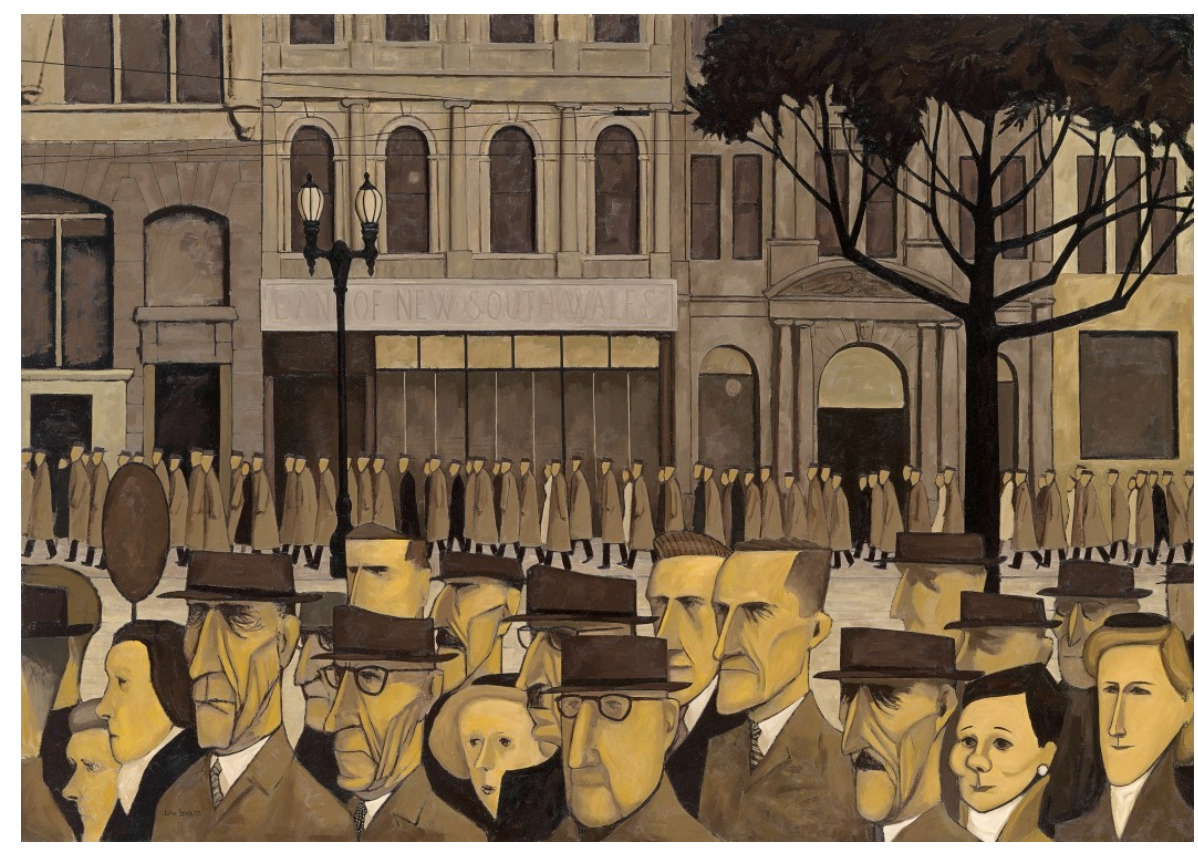

Figure 18.

John Brack, Collins St, 5p.m. 1955, 1955, oil on canvas, 114.8 x $162.8 \mathrm{~cm}$. Collection of the National Gallery of Victoria, Melbourne, purchased 1956 (3302-4). Digital image courtesy of National Gallery of Victoria, Melbourne (all rights reserved).

Take, for example, John Brack's Collins St, 5pm, which was voted the most popular painting in the National Gallery of Victoria in 2011 (Fig. 18).

Conventionally understood as a depiction of the monotony and alienation of post-war urban life, it might instead be taken as a measure of the settler capitalist project in Australia. The work does not even hint at the stolen land, the massacres, the sheep with jack-hammer hooves, the bush rolled and burnt, the gaping dusty mines, but all of these are the repressed extractivist foundations on which Collins Street was built, enabling the growth of settler populations, and the accumulation of settler wealth. Much of that wealth was deposited with and insured by the institutions that made Collins Street the financial heart of "Marvellous Melbourne", a major settler-colonial city. Yet, as is so often the case, the threads that connect exploitation and beneficiaries are invisible: all we can see in Collins Street are substantial buildings and well-dressed white people-the opaque material traces of the processes that generate wealth and direct it to some ends and not others. Is it an accident that the only business identified in the painting is the Bank of New South Wales, a crucial institution in the colonial transition from a penal to a capitalist economy? Brack's use of repetition and colour encourage us to think between poles of individuality and uniformity, but there is a much bigger story here, and there is a role for environmental historians in telling it. 
We non-Indigenous people need more resistant environmental historical readings of artworks that appear to have little to do with "environment", as meditations on how our social preoccupations and aesthetic inclinations have worked to decentre and mystify our intimate relationship with and dependence upon the living earth. 
Response by

Amanda Boetzkes, Professor of Contemporary Art History and Theory, University of Guelph

\section{Time for Political Ecology}

Sria Chatterjee's provocation poses trenchant questions about how to take hold of the emerging discourses of ecological crisis to renew art history and criticism. The fundamental terms of history and representation are indeed at stake as we struggle to surface the catastrophic effects of colonialism, slavery, capitalism, and resource extraction while insisting on resistance, responsibility, and justice through art.

Futurity hangs in the balance. The discourse of the Anthropocene is accompanied by a self-actualizing form of fatalism that forecloses the possibility of future life while erasing complex histories. It therefore appears to be subtended by a conviction not only that humans have engaged planetary life in an accelerated descent into a state of entropy, but also that the species is unable to reverse that trajectory. ${ }^{61}$ However, critics of the Anthropocene discourse suggest that the surrender to entropy reifies its destructive effects on the relationships between Indigenous people, land, and non-human animals. As the Potowotami philosopher Kyle Whyte posits, the dystopian imaginary that sees the climate crisis as a new emergency-taking the form of a sudden awakening to ecological catastrophe and the precarity of Indigenous territories and peoples-denies any understanding of the political disputes over Indigenous land that have been ongoing for centuries and that are still not resolved. 62 Indeed, some of these disputes are gaining momentum, like the Wet'suwet'en protest against the proposed Coastal Gaslink Pipeline that would cross nearly $700 \mathrm{~km}$ of Indigenous territory. By contrast to this present reality, the apocalypticism that underpins a settler understanding of the Anthropocene uses fatalism to preface contemporary political ecologies on the assumption that Indigenous peoples are endangered or have disappeared. Settler apocalypticism replicates the desires of colonial ancestors by pre-emptively nullifying the contemporaneity of Indigenous political struggles. 


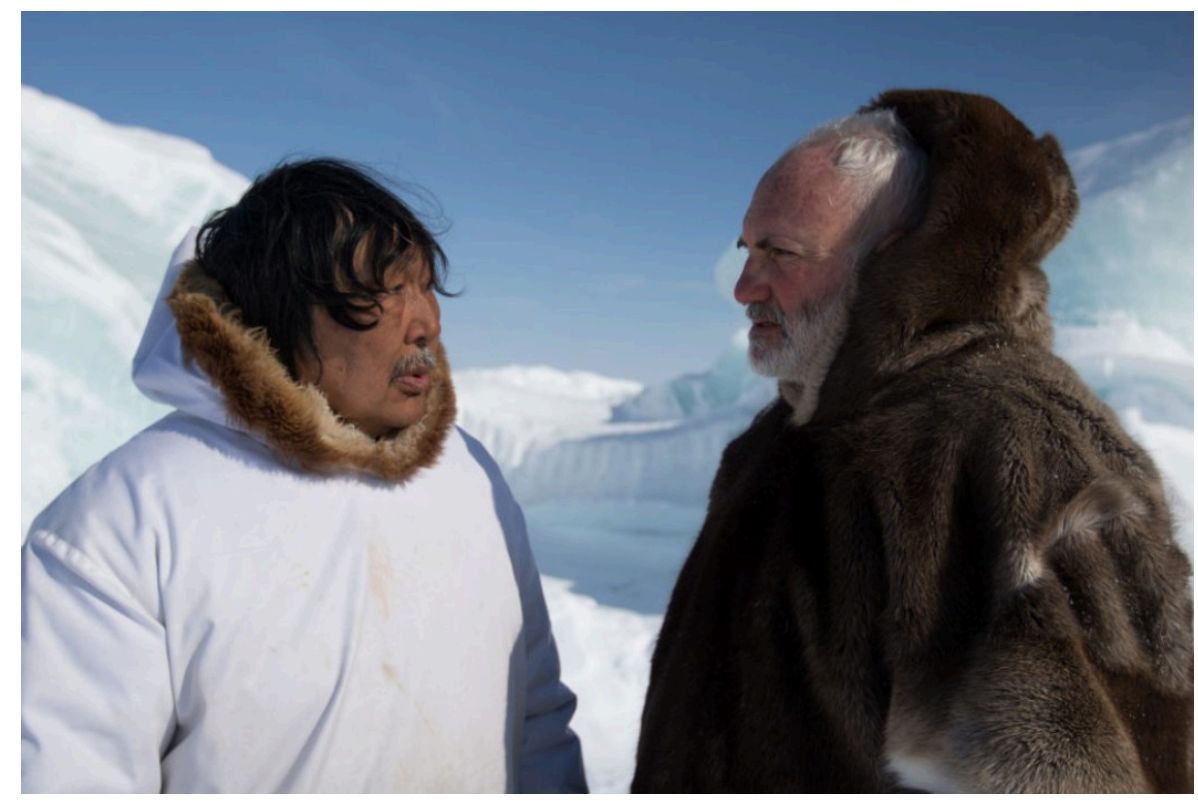

Figure 19.

Zacharias Kunuk, Scene with Apayata Kotierk as Noah Piugattuk and Kim Bodnia as Boss,, One Day in the Life of Noah Piugattuk, 2019, digital video installation, 112 minutes. Digital image courtesy of Isuma Distribution International. Photo: Levi Uttak (all rights reserved).

We can consider how art intervenes on the violence of entropy by representing history through non-entropic temporal modalities. Take, for example, the film One Day in the Life of Noah Piuggatuk (2019; dir. Zacharius Kunuk) produced by the Inuit art collective Isuma and which featured in the Canadian pavilion at the 2019 Venice Biennale (Fig. 19). The film is a scene of encounter between an Inuit hunter, Noah Piuggatuk, and a character named Boss, a white man sent from the Canadian government to order Piuggatuk and his kin to move to a settlement and send the children to a government school.

Kunuk's films might strike the settler viewer as slow, reflective, and replete with a sensibility for the elements. Likewise here, the encounter takes place over a protracted period of time sitting outside in a bright Arctic desert. The slow pacing activates the film's political force. Little happens except a highly controlled conversation in which Boss's agenda-the takeover of land-is held back from explicit articulation. Yet, this agenda is implicit in every word exchanged between the two. The film dilates an interaction in which Boss tries repeatedly-through everything from enticements like jam and sugar, to mild threats, to outright coercion-to weaken Noah Piuggatuk's position on the matter of resettlement. For Piuggatuk, the visit from Boss is an exercise in saying "no" to the resettlement, whether obtusely, exegetically, rhetorically, or directly. He never recants his decision. While the Inuit were ultimately forced out to resettle, the violence of this history underwrites the film but does not act on it to exert a repetition of the colonial logic. By 
decelerating entropy, the film unlocks a history of Inuit resistance to that colonial force in and through the counterforce of endurance. Isuma thus deploys an aesthetic orientation towards time and history in such a way as to assert its claim over the complex political ecology still unfolding in Inuit Nunangat, the land and ice of the Inuit in Canada. 
Response by

Julia Lum, Assistant Professor, Art History, Scripps College

Gabrielle Moser, Assistant Professor, Aesthetics and Art Education, York University

\section{The Invisible and Inalienable Wind}

Sria Chatterjee's essay ends with an urgent call for art historians to "critically rethink concepts that are fundamental to art history, such as time and scale, in ways that are productive for an intersectional eco-politics"-a call that requires stretching our thinking about the time-frame of climate change to include the world-altering effects of colonialism on the present, and to reimagine the scale of its impact on the environment. In this way, Chatterjee echoes and amplifies the important work done by Indigenous, Black, and diasporic scholars in critiquing the discourse of the Anthropocene, particularly Heather Davis and Zoë Todd's insistence that we date the start of climate change in the early seventeenth century with the profound transformation of the Americas through modern colonialism: the beginning of the plantation slavery system, and the attendant terraforming of the land through deforestation, extraction, and the relocation of millions of humans, plants, and animals. 63

Resetting the start date of the Anthropocene asks us to imagine how air, water, the subterranean, and its many non-human inhabitants have survived and lived beyond anthropogenic colonialism's world-ending effects. As Macarena Gómez-Barris argues, Western landscape tradition and Eurocentric visual theories have tended to "ignore the weight of colonial seeing, neglecting its earlier forms of power", which we, in turn, risk reifying as the sum of their extractive powers. $\frac{64}{H o w}$, as art historians interested in the political investments that drive the ways the land is imagined and depicted in the (former) British Empire, can we insist on seeing the verticality of colonial violence and its "material consequences ... that affect bodies and land", as Davis and Todd argue? 65

One possible answer lies in the work of the wind. In 1806, the British admiral Sir Francis Beaufort created a thirteen-level index that visualized the effects of wind which, in turn, helped accelerate maritime travel, colonization, and global capitalism. Over these last months, we have become all the more aware of air as something invisible but material, a precious but dangerous conduit that heeds no borders. A contrast to the visible "plague winds" of 
industrializing Britain, $\underline{66}$ COVID-19 poses an imperceptible threat to the airas-commons; the bodies of Black and Indigenous peoples are as susceptible as ever. 67

Secwépemc and settler artist Tania Willard's artwork Liberation of the Chinook Wind (2018) responds to attempts to measure the wind's effects. But instead of registering linear thresholds, Willard's installation records its entanglements-with histories of language and species migration. $\underline{68}$ As part of The Work of Wind, a massive outdoor exhibition in Mississauga, Ontario that took the Beaufort scale as its framing logic, Willard installed four windsocks emblazoned with the words "CLAIM", "WATER", "THRASH", and "FIGHT" along the shores of Lake Ontario (Figs 20 and 21). As the socks filled with the winds, computer software translated the weather data into poetry, using language drawn from recent government reports on fishery management in the Great Lakes ecosystem, the University of Toronto Mississauga's official territorial acknowledgement, Indigenous land and water claims for the region, and anthropologist James Teit's ethnographic study of the Coast Salish peoples from 1909 (Fig. 22).

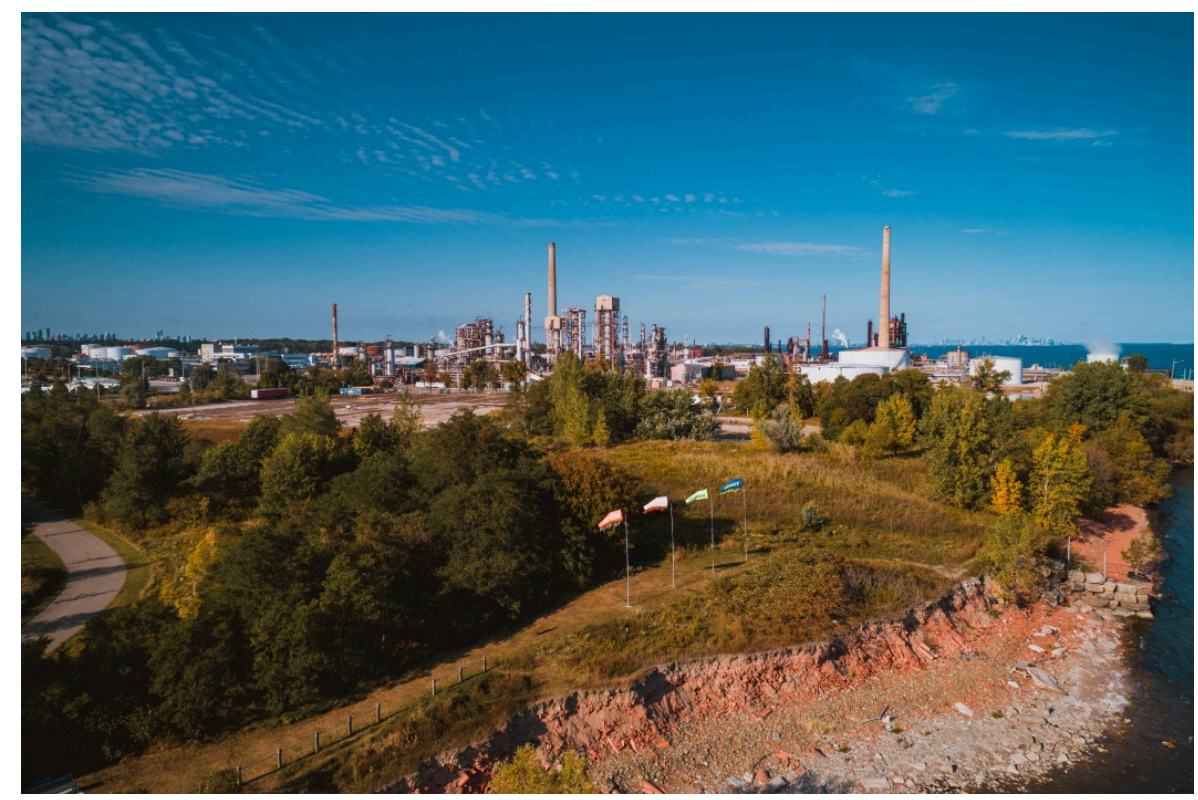

Figure 20.

Tania Willard, Liberation of the Chinook Wind, Commissioned by Blackwood Gallery for The Work of Wind: Air, Land, Sea, 2018, photograph. Digital image courtesy of Blackwood Gallery. Photo: Spiral Mountains Media (all rights reserved). 


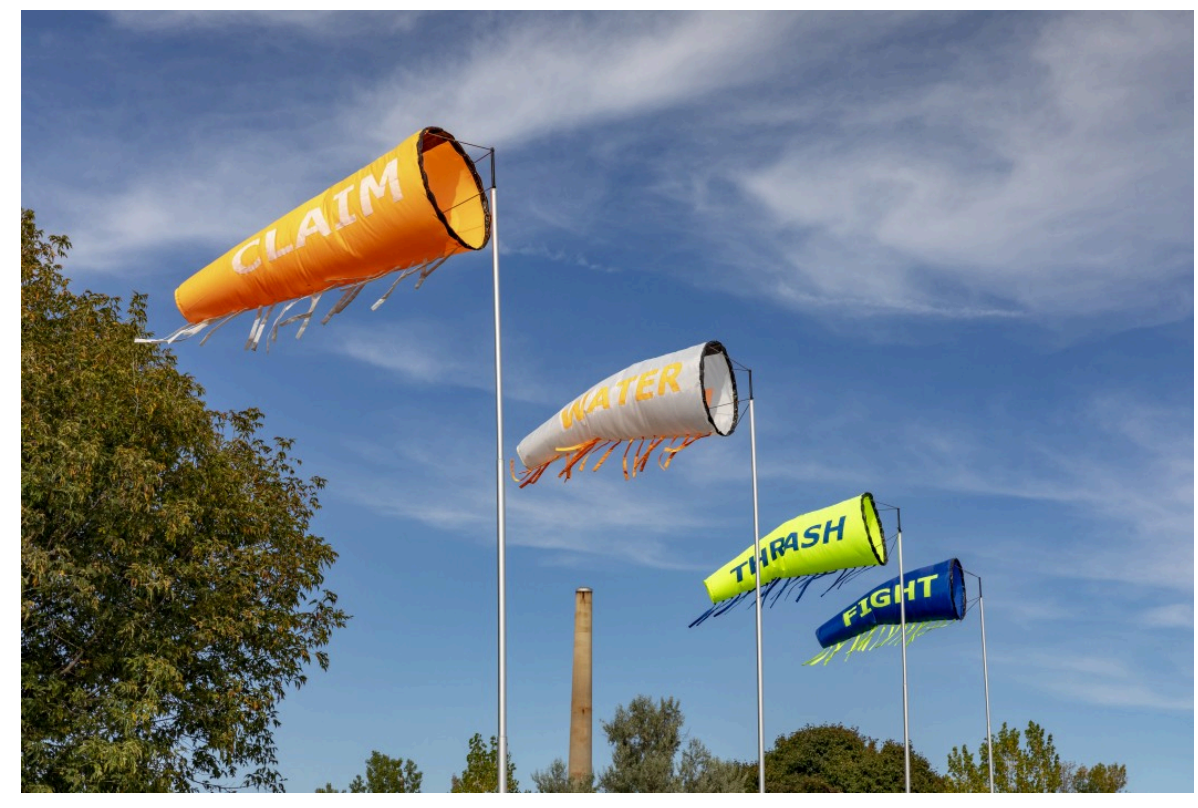

Figure 21.

Tania Willard, Liberation of the Chinook Wind, Commissioned by Blackwood Gallery for The Work of Wind: Air, Land, Sea, 2018,

photograph. Digital image courtesy of Blackwood Gallery. Photo: Toni Hafkenscheid (all rights reserved). 


\begin{abstract}
Water
legacy contaminants

wildlife consumption

on the banks of the River

on the banks of the River

on the banks of the River

on the banks of the River

legacy contaminants

legacy contaminants

legacy contaminants

the traditional territory of the Mississaugas of the Credit

wildlife consumption

access

wildlife consumption

on the banks of the River

the traditional territory of the Mississaugas of the Credit

the traditional territory of the Mississaugas of the Credit

on the banks of the River
\end{abstract}

\title{
Figure 22.
}

Tania Willard, Poem created as part of Liberation of the Chinook Wind, Commissioned by Blackwood Gallery for The Work of Wind: Air, Land, Sea, 2018, photograph. Digital image courtesy of Blackwood Gallery. Photo:

Spiral Mountains Media (all rights reserved).

Much like the poems generated by the installation-which mix the imperative tones of state interests in "increasing production" with Indigenous claims to access, stewardship, and concerns about contamination-the project integrates histories of cultural contact and interspecies conflict. Willard's title references the introduction of Pacific Chinook salmon into Central Canadian waters in the 1960s as a way to control invasive species and as a catalyst for sport fishing; Chinook were, in turn, introduced to the rest of the Great Lakes through transatlantic trade. Evoking this migration, as well as the development of Chinook jargon as a hybridized trade language in the Northwest Coast of North America, Liberation of the Chinook Wind looks to the invisible and inalienable power of the wind to challenge the ways that Indigenous "bodies and lands are always disappearing in the 'floodwaters of colonization'", as Willard describes it. ${ }^{69}$ By creating a linguistic hybridization 
of its own-poetic meaning that has detached itself from the syntactical coherence of its English language sources-Willard's project invites viewers to understand landscape as animated by and through relationality.

While Liberation of the Chinook Wind harnesses air's authorship, the project equally plumbs the lakeshore's depths, inviting viewers to imagine the ways that settler colonial violence extends into and below the water line. ${ }^{70}$ As Todd has argued, "water can be polluted in other ways-polluted with memories of colonial events, littered with shipwrecks and other materials that we have yet to know the long-term social or spiritual or physical impacts or implications of". $\underline{71}$ The poetic refrain "legacy contaminants", autogenerated by Willard's wind socks, cascades into stratified layers throughout the poem upon output, much like the depths of such chemicals that linger in soils and other ecosystems long after industrial production has ceased. Willard's project highlights such devastating long-term consequences while also suggesting chance interactions outside of anthropogenic determination, and in so doing creates landscapes as products of intentional and unintentional design. $\underline{72}$

These bodies-of fish and human, of wind gusts and shipwrecks-are not invisible in the history of British art, but require a different attunement to be read for their implication in the colonial origins of climate change. Thinking alongside Chatterjee, Todd, Willard, and Gómez-Barris, how might art historians imagine the landscape from the submerged perspective of the fish, whose experience of the times and spaces of climate change are necessarily embedded in the longer, intersectional history of colonialism? 
Response by

Jennifer Mae Hamilton, Lecturer in Literary Studies, University of New England

\section{Weathering Then, Now, and Always}

What I appreciate most about James Barry's painting is this: no one else is affected by the weather, only Lear (Fig. 23). His hair is blown horizontal. The title of the image is King Lear Weeping Over the Dead Body of Cordelia. As with the conventions of romanticist painting, Barry has playfully turned emotion into gesture. On top of this, the mythical and religious aspects of this image have been neatly documented, but rarely is the material impossibility of the strangely targeted wind in the old King's white locks noted as contributing to the mythic significance of the tableau. $\underline{73}$ What happens when this aspect of the painting is centred in our attention, not as a simple romanticist trope but as a strange conjuring of the weather for poetic ends?

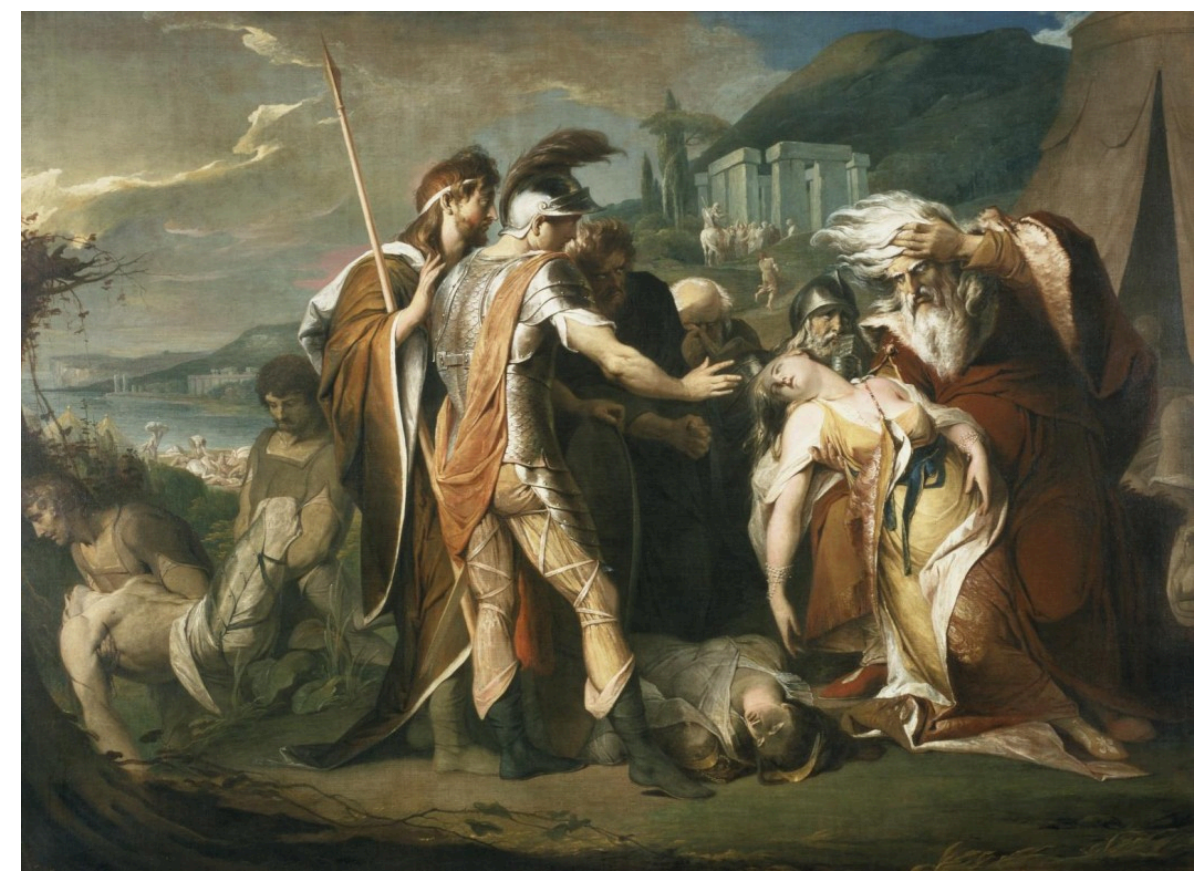

\section{Figure 23.}

James Barry, King Lear Weeping Over the Dead Body of Cordelia, 1786-8, oil on canvas, $269.2 \times 367 \mathrm{~cm}$. Collection of Tate (T00556). Digital image courtesy of Tate (CC-BY-NC-ND 3.0).

Lear is "weathering" the situation. Weathering is "a particular way of understanding how bodies, places and the weather are all inter-implicated in our climate changing world", but also, anachronistically, it can be a way of 
thinking about the connection between these things across time in a stable climate. $\stackrel{74}{ }$ Lear's individual emotions, his sense of social obligation, the literal atmospheric conditions, the ideological paradigm all combine to produce the meaning of the wind in his hair. He is very upset and we are all supposed to know it and recognise it. But, as Astrida Neimanis and Rachael Loewen Walker remind us: "we are always weathering". ${ }^{75}$ In the context of Barry's painting, everyone is also weathering, not just Lear. They are all weathering the uneven fallout from Lear's bad decisions. Lear may be very windswept by all this, but keep in mind it is Cordelia that is dead. We are always weathering, but as Neimanis and I elaborate in a later piece, we are always weathering but not always in the same way. $\underline{76}$ Exploring the similarities (we are always weathering) and differences (but not in the same way) between bodies in the world today is an urgent task for a time of ecological crisis where both the power and finitude of the earth-bound human is commanding our attention in new and alarming ways. It can be a question we ask of historical images (how were they weathering then?), but it can also be a question we explore in contemporary art praxis (how are we weathering now?).

In a very different time and place, and working under a different set of aesthetic instructions, the art-academic group "The Weathering Collective" created the "The Weathering Map of Microclimates and Approximate Watery

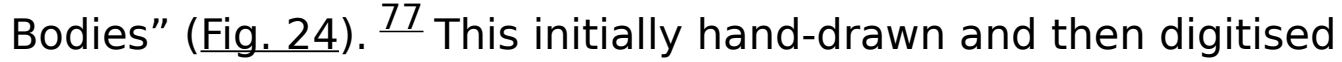
representation of local microclimates examined the specific localised weatherings of the group. The microclimates were a stunning temperature shift when one ascends a hill from a river flat, a beach with a new baby, a basement in Belgium, moisture seeping unwanted into a house due to shoddy construction, and the particular shade of a specific tree. The group sought to observe differences across the shared experience of the weather by identifying things that shape the weather for us. The weathering differently but simultaneously was imagined and represented together in a single map, with the aim of turning a theoretical concept into a series of embodied and material questions that reflected upon in situ then represented for a spectator. We were motivated to visualise these microclimates because they fall outside the dominant way in which the weather is measured. For all the known variation captured by meteorologists, the weather report ascribes a single temperature for an entire region as if such differences did not exist. Our map resisted that particular institutional narrative and told another story. 


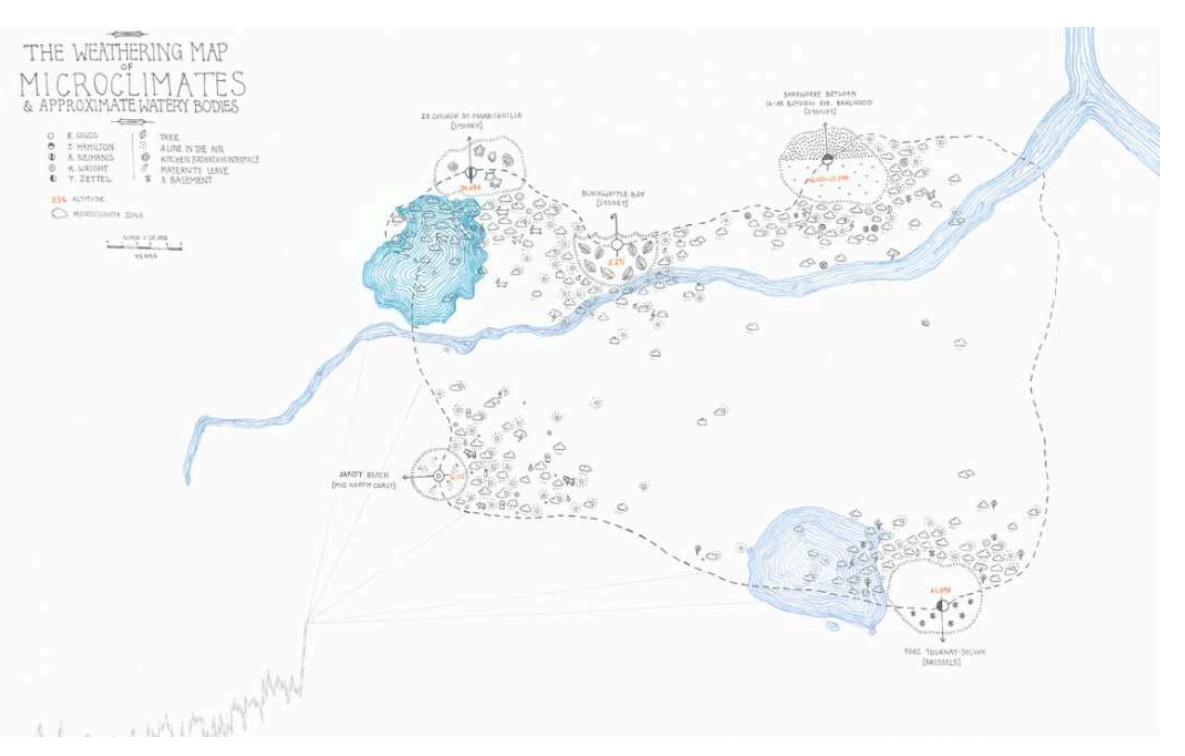

\section{Figure 24.}

Drawn by Tessa Zettel in collaboration with the Weathering Collective (Astrida Neimanis, Rebecca Giggs, Kate Wright and Jennifer Mae Hamilton), The Weathering Map of Microclimates \& Approximate Watery Bodies, project map. Digital image courtesy of Jennifer Mae Hamilton (all rights reserved).

What kind of art and what kind of art history do we need most at this time? The question of the relevance of analysing a romantic painting versus my text/drawing/digital mapping collaboration interests me in this moment of global ecological, medical, and economic crisis. Barry's image certainly cannot, in itself, be innovative. It is an old scene painting and the conclusion to Shakespeare's tragedy of King Lear. In Shakespeare's literary narrative, this scene represents the denouement of a tragedy where an old man does a shockingly bad job at giving up power. $\frac{78}{}$ As such, it is stunningly relevant to the present moment, just before Donald Trump (presumably) cedes power, as he is more concerned with his own image than the carnage before him. The image is a cautionary tale about such power, hierarchy, and consequence. Looking at it today suggests that we have not heeded its warning. The point about relevance here then is that critical history will never "run out of steam". ${ }^{79}$ But although it is important to continue with critical historical analysis, it should not be all that we do: we need to destroy and create.

How best to do that? Claire Bishop, in Artificial Hells, thought that participatory art-the kind of art that really aimed for social transformation-was the worst kind of art. While Bishop's text is ultimately too cynical about participatory art, too critical to be entirely useful, at the same time, I find one of her most provocative claims worth a bit more thought: "at a certain point art has to hand over to other institutions if social change is to be achieved: it is not enough to keep producing activist art". $\underline{80}$ "The Weathering Collective" is not a group of consistently practising activist 
artists, nor are we especially participatory, but we do realise that historical investigation and critical research of any kind is not enough. Practice, creation, and new modes of participation are required. We are researchers of environmental crisis and if the environmental crisis is a material problem, it matters what we do and how we do it. We need to be changing our work practices and the world towards which we are working. After all, this crisis was built, not conjured. Thus, the only way out is a different kind of building.

If artists, however, cannot be artists and give over too much to "other institutions", the destruction of the dominant order that is central in the creation of good art will be lost as well. Art and art history can do anything, and can do it by any means necessary, as long as it is making those most sheltered slightly more exposed and those most exposed quite a lot more sheltered. 
Response by

Kate Flint, Provost Professor of Art History and English, University of Southern California

\section{The Resilience of the Dandelion}

Sria Chatterjee asks that we understand the ecological crisis as an intersectional one: one that acknowledges the interplay not just of different disciplines and approaches in our critical analysis but also of past, present, and future, and of vastly different physical and temporal scales. Such an emphasis on entanglements is, as she acknowledges, hardly new. The pioneering American ecologist George Perkins Marsh concludes Man and

Nature (1864) with a paragraph titled "Nothing Small in Nature". $\underline{81}$ His argument throughout is that all natural phenomena are inter-related-that one shouldn't discount the part that even the most insignificant appearing species play in the functioning of the whole, and that human disruption of even the smallest part of the natural world can have far-reaching consequences. "[I]n the vocabulary of nature, little and great are terms of comparison only; she knows no trifles." 82

Marsh's principles are, by now, a cornerstone of ecological thinking. They have their influential English counterpart in John Ruskin's statement that "small things and great are alike part of one mighty whole"-a comment underpinning not just his own criticism and drawing, but also that of his many artistic followers who obeyed his imperative to observe nature closely. $\underline{83}$ Belief in the value of even the most apparently unimportant element in the natural world received repeated theological support, not least from the many clergy contributing to the dissemination of Victorian natural history. 84 But what might we gain from considering the "small" and easily overlooked when scrutinising nineteenth-century art?

Take the dandelion: not only a commonplace plant but also a persistent, if unremarked upon, presence in paintings. On both sides of the Atlantic, its yellow flowers and fluffy seed-heads appeared: in nursery rhyme illustrations and on decorative tiles; and in nostalgia-filled depictions of children playing in meadows or of pretty young girls blowing on Henry Thoreau's "complete globe, a system in itself" to ascertain the affection of their lover. $\underline{85}$ The hidden history of the dandelion is embedded in such images: the wayward seeds disseminating through the air in a way that ensures its global ubiquity; the plant's changing status from rural staple, its leaves used in salads and diuretic teas, to tenacious weed, attacked through herbicides that reduce biodiversity. 
The contemporary environmental artist Edward Chell considers taxonomic borderlands through depicting the wildflowers found in liminal places-motorway verges and medians (Fig. 25). He explores an environment choking with pollutants. His silhouetting technique borrows from the late eighteenth century, retaining the fragile shapes of roadside plants: hairy bittercress, creeping buttercup, and, of course, the dandelion. Although beautiful, these are toxic records: Chell mixes ink with the residue of the internal combustion engine taken from the place where he picked each flower: unburned hydrocarbons, carbon monoxide, nitrogen oxides, and particulate matter. These weedy sites mock the Victorian visual tradition of pastoral meadows; they are micro-habitats at once degraded, and yet sustaining diverse, persistent vegetation.

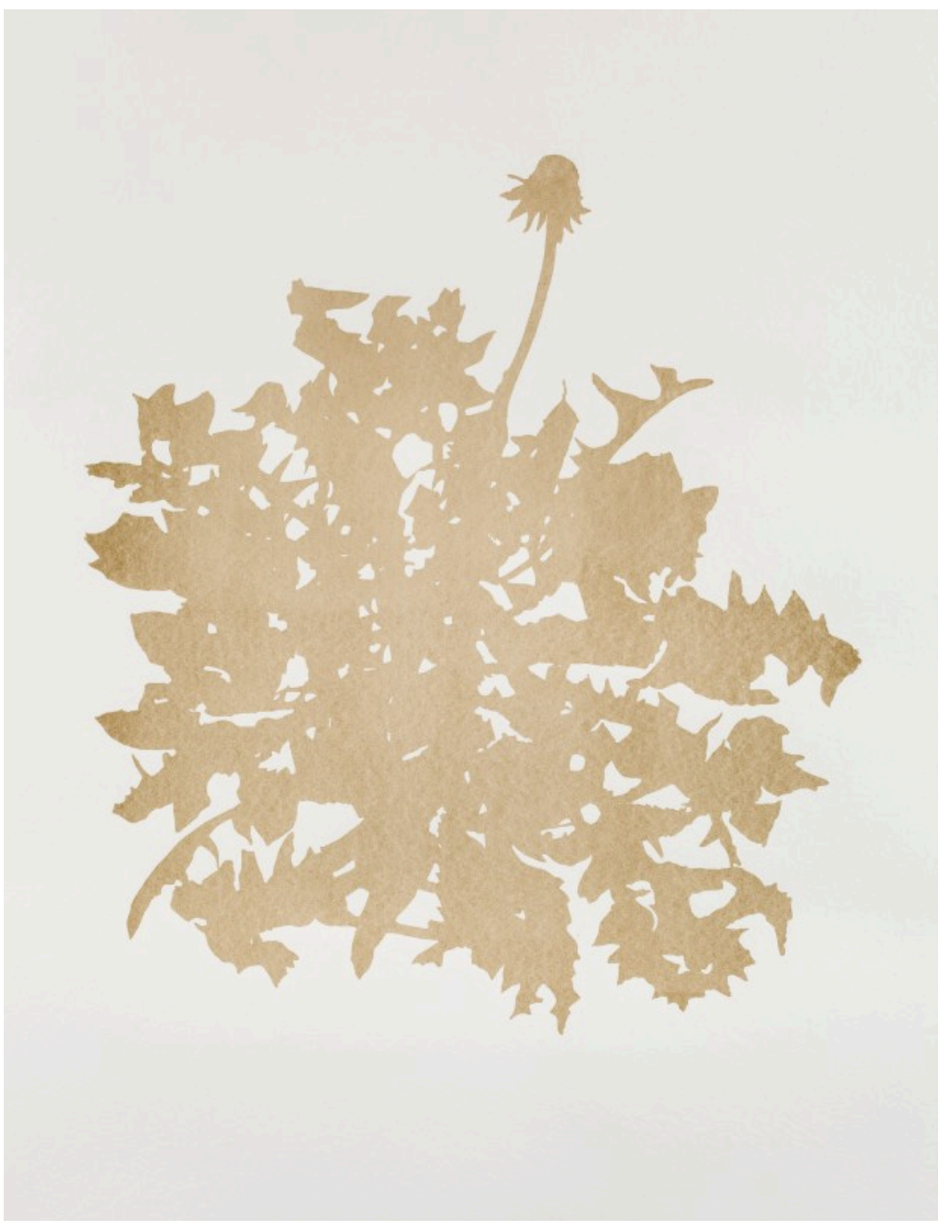

\section{Figure 25.}

Edward Chell, Dandelion Taraxacum officinale: Road Dust M4, 2011 , road dust on $400 \mathrm{gsm}$ acid free watercolour/drawing paper, $135 \times 105 \mathrm{~cm}$. Digital image courtesy of Edward Chell / Photo: kind permission of Peter Abrahams - Lucid Plane. 
In The Sky of Our Manufacture, one of the most important recent studies of the relationship between culture and anthropogenic climate change, the literary critic Jesse Oak Taylor describes the "challenge to the environmental imagination ... to render visibly present these often invisible, distributed catastrophes, a challenge that inverts the common ecocritical desire to engage in an unmediated relation to the natural world". $\underline{86}$ Our challenge as art historians is to understand the environmental change that is latent within the art of earlier periods. In this context, Chell's art is a critical provocation, borrowing from the past to help us think through the urgency of our present moment. It prompts us to look back to all those overlooked dandelions-and other wild flowers of meadow and wayside-in Victorian paintings. In their future lie attacks from herbicides, from pollution-including the by-products of the petroleum industry-and the decimation of biodiversity at the hands of corporate agriculture. Latent within these images is the long process and global reach of environmental violence: we can no longer conscientiously think of them as idealised relics of a more rural past. 
Response by

Lizabeth Paravisini-Gebert, Professor of Hispanic Studies on the Randolph Distinguished Professor Chair, Vassar College

\section{Peter Doig's Threatened Ecotone}

Grande Riviere, Trinidad, as the vultures-the corbeaux-await (Fig. 26).

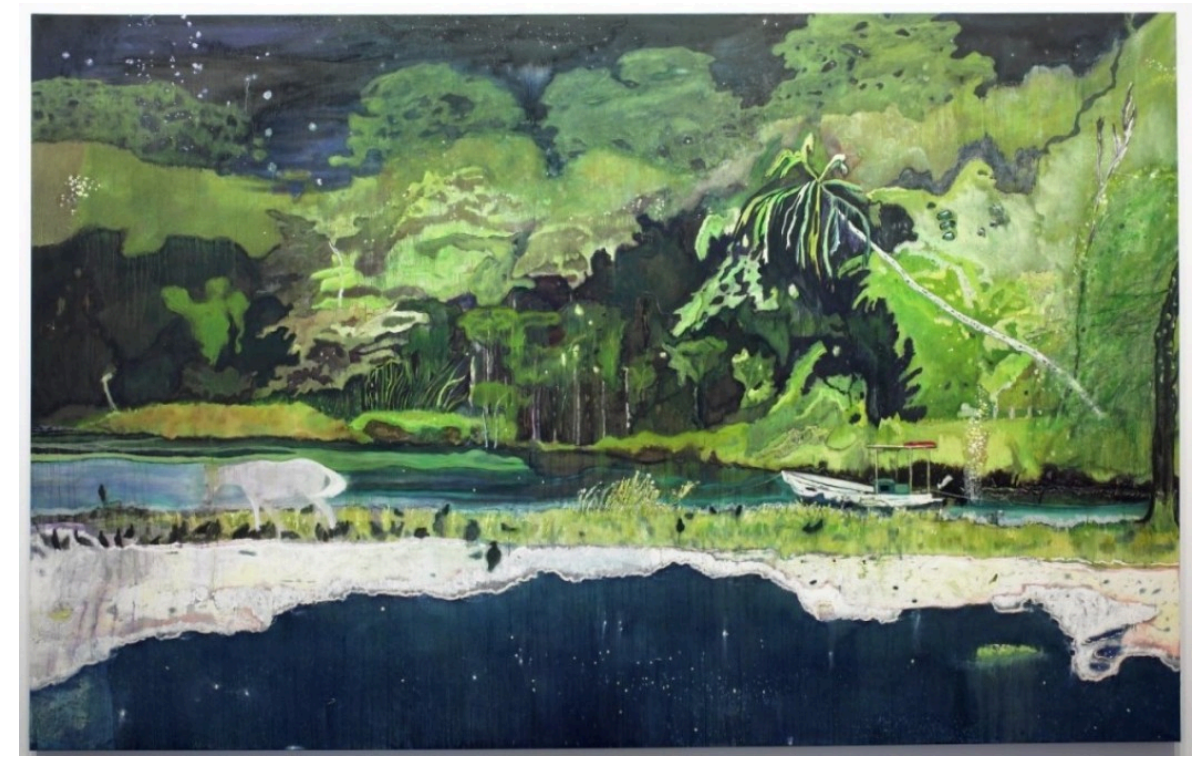

Figure 26.

Peter Doig, Grand Riviere, 2001-2002, oil on canvas, 228.8 x $358.4 \mathrm{~cm}$. Collection National Gallery of Canada (41147). Digital image courtesy of Peter Doig/Victoria Miro Gallery (all rights reserved).

Writing about this painting-Doig's first Trinidadian canvas-in their book Morning, Paramin (2016), Derek Walcott evokes Conradian scenes, emptiness, and absences, as "the 'green' forest drips to devour the explorer". $\underline{87}$ Eerie and spectral, Doig's landscape speaks of history-of the history of the Big River ecotone as well as the history of the colonization of the American tropics, of how a place as remote and beautiful as the mouth of the river that gives its name to the village of Grande Riviere has retained its ominous enchantment as the next catastrophe lies in wait.

Grand Riviere captures what is perhaps Trinidad's most unspoiled ecotone, a term used in ecology to describe an abrupt transition space between adjacent community types-river, sea, forest-forming a narrow ecological zone between them defined primarily by its dynamism, by patterns, and interactions between communities that have led to radical transformations in ecological conditions led by abrupt changes in human societies. The landscape, dreamlike-nightmarish-captures the three distinct zones that 
mark the ecotone: the dark, menacing, and attacking sea; the grand river that invited explorers into the island's forested interior; and the narrow strip of beach where a forlorn horse (a colonial invasive species) is watched by a committee of Trinidad's ubiquitous black vultures, potential "erasers" of a history of colonial presence. Their stance of eager anticipation and too close proximity to the horse wryly reminds us of why their gathering as a "committee" can quickly become a "wake" of vultures.

Grand Riviere's power lies in its layering of histories, but also on what it tells us about possible futures. Its geographical specificity-it is a landscape that can be visited, experienced first-hand-evokes a history of extraction and exploitation of the land as a site of famous but abandoned cacao plantations, now reforested and home to growing biodiversity. Its forest represents a victory against colonial deforestation, as nature re-imposes itself over the debris of colonization. Its sands are now famous as vital nesting spaces for endangered leatherback turtles; and turtle conservation, ecotourism, and artisanal fishing have replaced exploitative practices brought by colonization in its wake. The painting echoes these developments in the solitary river tour-boat placidly resting on river waters.

Grand Riviere's lasting impact, however, is as a reminder of the threat facing vulnerable ecotones like that formed at the place where the Big River, the sea, and the vulnerable shores of the village of Grande Riviere meet. It lies on that dark mirror-like surface that stands for the encroaching sea and its ultimate ability to erase, to obliterate the vulnerable narrow shore of Doig's lovingly moonlit painting. The dark space capturing the reflections of the stars, catching the moonlight as it bounces against the trees and the bending palms, speaks to me of the threat posed by sea-level rise as the final layer of erasure threatening the American tropics to which Trinidad belongs. Walcott-whose love for Trinidad Doig shares-writes of there being "some vague horror inside the unchristened bush": Doig acknowledges the horrors of the dark and foreboding bush but points to the sea and other terrors rising from below. $\underline{88}$ 
Response by

Simon Schaffer, Professor of History of Science, University of Cambridge

\section{Nature as Other, Others as Natural}

Sria Chatterjee makes the persuasive and significant argument that the contemporary ecological crisis puts questions of representation at the centre of discussions about the relationship between nature and culture. She urges us to recognise the reorganisation of the work of representation, to make evident otherwise unremarked historical pathways, whose denial presents pressing challenges for criticism and effective action in the present. A telling phrase here is the claim that "the representation of nature as other is a EuroAmerican construct". Within scientific disciplines and methods produced in that setting, companion claims about the representation of others as somehow natural-allegedly devoid of complex social life or even recognisable histories-have been at least as vicious and important.

The advent of a carbonised economy in the wake of the development of the stationary steam engine and its adoption across key industrial sectors of expansive capitalism has been proposed as the decisive moment when human action first became a planetary force of geological scale. ${ }^{89}$ That conjuncture was also when the modern order of the natural sciences began to be established, and when a polemical claim was powerfully urged by European intelligentsia keen to discriminate between bearers of culture and occupants of what was taken to be a pre-modern natural world. They argued that the exotic and the ancient must be identified with each other-it was as though Europe's ancestral past could be visited, surveyed, mastered, and expropriated through curious and aggressive travel to other regions of the planet. The work of making images of those regions played an indispensable role in the forging of this militant notion of history and genealogy, of nature and alterity. It still does.

One of the more significant formulations of the principle was constructed in 1800 as a brief written by the lawyer and philosopher Joseph-Marie Degérando for a planned French naval expedition to the South Pacific and Australasia, launched in direct competition with British projects to exert control over the southern continent. $\underline{90}$ He argued the expedition would be voyaging into French society's own past, to the primitive roots of the process of human development that had reached its culmination in the contemporary republic. He compared this project with the French invasion of Egypt, launched eighteen months earlier. 
In the years around 1800, peoples and cultures such as those of Egypt or Australasia, under ferocious attack and exploitation, served European observers as means to determine those same observers' status. Indigenous peoples were understood as natural types, to be contrasted with, and often treated with contempt by, scientific scrutiny. Both among Egyptian fellahin and among Tasmanian Aborigines, surveyors subjected those they encountered to precise tests of capacity for labour, with the aim of imposing an allegedly universal scale of value on what they understood as natural peoples. In Tasmania, an engineering device designed to measure the force exerted in disciplined tasks, the dynamometer, was used to compare performances by Indigenous subjects and by Europeans: the results, so it was claimed, indicated a natural association between civilisation and strength, primitivism and weakness (Fig. 27). $\underline{91}$ Exterminism and exploitation were underwritten by systems of surveillance-and they were met with continuing resistance and cultural affirmation. ${ }^{92}$ It is telling that among the principal proponents of this naturalising doctrine of the remote as primitive were also enthusiasts for the adoption of steam engineering in industrial

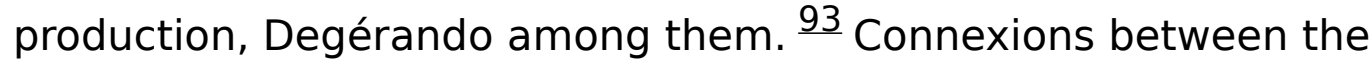
development of fossil capitalism and of European racialist sciences matter. These forms of capital production and resource extraction became at this moment both a motive for imperial aggression and a key weapon in the struggle. They help to make better sense of representational practices of naturalists and cartographers, missionaries and surveyors, who took part in such enterprises. $\underline{94}$ 


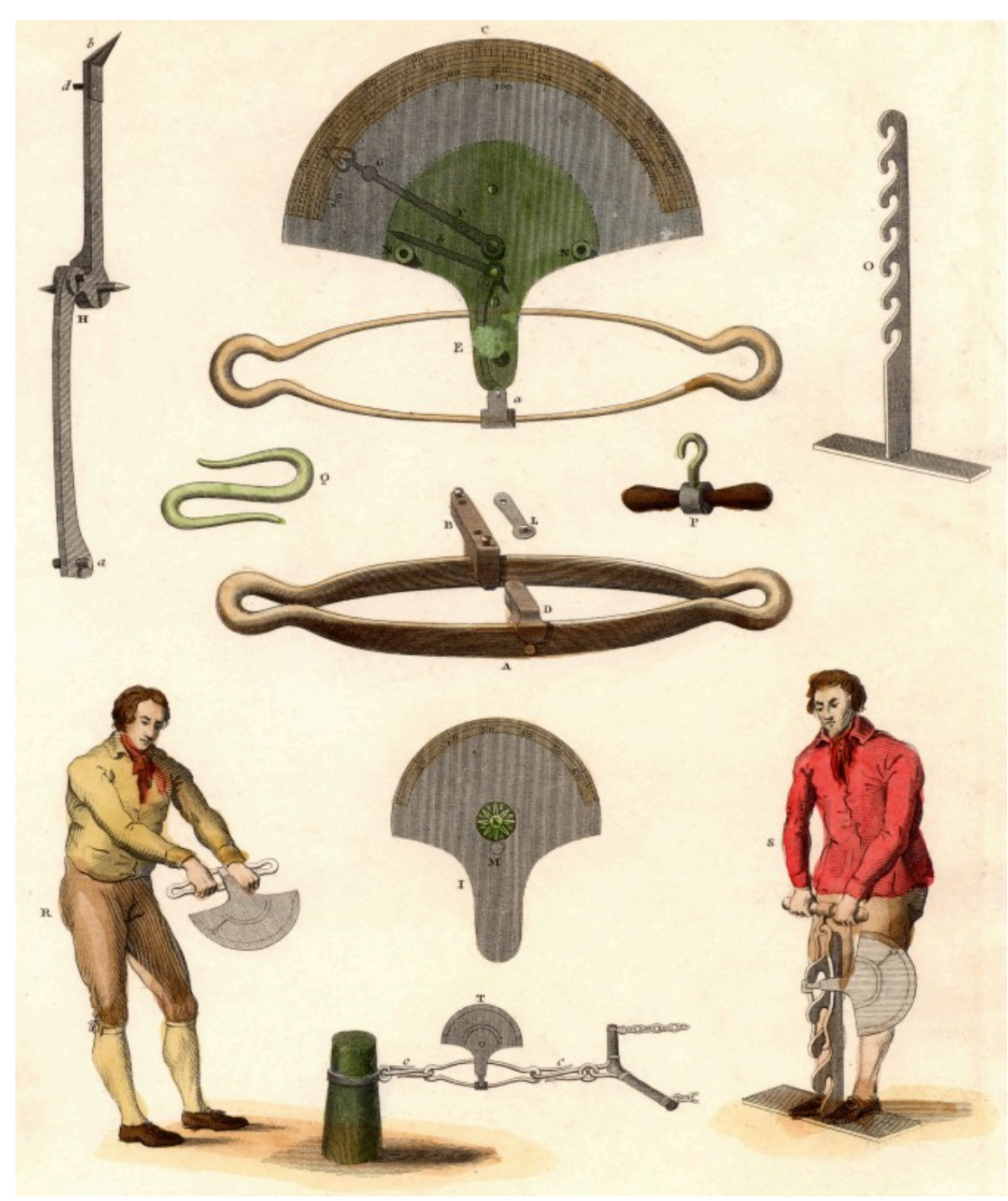

Figure 27.

Dynamometer, an instrument for measuring mechanical force or power, designed by Edme Regnier. Engraving from Encyclopaedia Londinensis (London, 1803). Digital image courtesy of World History Archive / Alamy Stock Photo (all rights reserved).

There is thus a need to overhaul accounts of representation, polemics about the iconography of peoples and worlds Europeans found alien, that have often governed the exposition of visual and material culture made in these encounters and struggles. Such images and charts should not be treated as effortlessly hegemonic nor uncontested marks of authority, but rather must be understood through potent counter-signs of Indigenous agency. $\underline{95}$ They can help reposition stories of climates in conflict and transformation. During the decades around 1800, the notion of climate changed its sense in most European languages. Until then, it had meant a geographical zone defined by latitude. European philosophers and geographers, naturalists, and physicians debated whether the character of a region's inhabitants were governed by their climate, that is, determined by their geographical position. But from then on, climate came to mean a set of dynamic atmospheric and thermal 
conditions often subject to the effects of human action. This was the moment when it first became possible to say that climates could change and be changed.

The backers of the occupation of Egypt reckoned "a time will come when this august land will regain under the influence of the arts of Europe its ancient splendour". Orientalists' notion of a degenerate East redeemed by Western politics was hitched to engineers' ambition for climate change: "these happy changes in peoples' manners and relations will be the certain consequences of the application of the arts to the natural properties of climates". 96 This was a key stage both in the naturalisation of the Other within imperialist European erudition and also in the socialisation of nature within aggressive European sciences. There were telling connections between patterns of representation and the pernicious myth of an empty landscape, a nature fit for exploitation and lacking a viable modern history separate from and

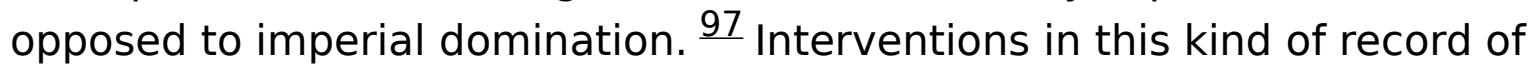
agency and conflict may help the call to speak to the complex entanglements of states, corporations, and institutions in the roots of the current crisis.

\section{Footnotes}

1 John Barrell, The Dark Side of the Landscape: The Rural Poor in English Painting 1730-1840 (Cambridge: Cambridge University Press 1983).

2 Kathryn Yusoff, A Billion Black Anthropocenes or None (Minneapolis, MN: University of Minnesota Press, 2018).

3 See: Katherine McKittrick, “Wires, Kerosene, Data”, Holberg Symposium in Honour of Paul Gilroy, Bergen, University of Aula, 4 June 2019.

$4 \quad$ Will Steffen, Jacques Grinevald, Paul Crutzen, and John McNeill, “The Anthropocene: Conceptual and Historical Perspectives", Philosophical Transactions of the Royal Society A 369, no. 1938 (2011).

5 Yusoff, A Billion Black Anthropocenes or None; and Laura Pulido, "Racism and the Anthropocene", in Gregg Mitman, Marco Armiero, and Robert S. Emmett (eds), Future Remains: A Cabinet of Curiosities for the Anthropocene (Chicago, IL: University of Chicago Press, 2017)

6 Françoise Vergès, "Racial Capitalocene: Is the Anthropocene Racial?" Verso Blog, 30 August 2017, https://www.versobooks.com/blogs/ 3376-racial-capitalocene.

7 See Monique Allewaert, Ariel's Ecology: Plantations, Personhood, and Colonialism in the American Tropics (Minneapolis, MN: University of Minnesota Press, 2013); Anna Tsing, "Unruly Edges: Mushrooms as Companion Species: For Donna Haraway", Environmental Humanities 1, no. 1 (2012): 141-154.

8 Saidiya Hartman, Lose Your Mother: A Journey Along the Atlantic Slave Route (New York: Farrar, Straus and Giroux, 2007).

9 Londa Schiebinger, Plants and Empire: Colonial Bioprospecting in the Atlantic World (Cambridge, MA: Harvard University Press, 2007), 5 and 11.

10 Ursula K. Heise, Sense of Place and Sense of Planet: The Environmental Imagination of the Global (Oxford: Oxford University Press, 2008), 59.

11 Tommy Orange, There, There (London: Random House, 2018), 11.

12 The concept of intersectionality, which emerged from the work of Black feminist legal theorist Kimberlé Crenshaw demands that overlapping systems of oppression tied to race, class, gender, and sexuality are not studied in isolation. See "Kimberlé Crenshaw on Intersectionality, More than Two Decades Later", Columbia Law School, 8 June 2017, https://www.law.columbia.edu/news/archive/kimberle-crenshaw-intersectionality-more-two-decades-later.

13 Hal Foster, "The Artist as Ethnographer?", The Traffic in Culture: Refiguring Art and Anthropology (Berkeley, CA: University of California Press, 1995), 302-309; Yates McKee, Strike Art: Contemporary Art and the Post-Occupy Condition (London: Verso Books: 2017); and T.J Demos, Against the Anthropocene: Visual Culture \& Environment Today (Berlin: Sternberg Press: 2017). 
14 W.J.T. Mitchell, "Imperial Landscape", in W.J.T. Mitchell (ed.), Landscape and Power, 2nd edn (Chicago, IL: University of Chicago Press, 2002 [1994]), 5-34.

15 Juanita Sundberg, “Decolonizing Posthumanist Geographies”, Cultural Geographies 21, no. 1 (2013), 35.

16 For more on the winning entries, see Simon Levey, "Winning Entries of First Grantham Art Prize Stir Emotions at Exhibition Opening", Imperial College, London, 26 April 2019, https://www.imperial.ac.uk/news/191007/winningentries-first-grantham-art-prize/.

17 Erik Swyngedouw, "Apocalypse Forever? Post-Political Populism and the Spectre of Climate Change", in Theory, Culture \& Society 27, nos 2-3 (2010): 213-232.

18 Demos, Against the Anthropocene.

19 For examples and a fuller discussion, see Ros Gray and Shela Sheikh, "The Wretched Earth: Botanical Conflicts and Artistic Interventions", Third Text 32, nos 2-3 (2018): 163-175, DOI: 10.1080/09528822.2018.1483881.

20 A good example of the changing field is the recent special feature: Catherine Grant and Dorothy Price, eds., “Decolonizing Art History”, Art History 43, no. 1 (February 2020): 8-66, https://doi.org/10.1111/1467-8365.12490.

21 Elsa Hoover, "Oceti Sakowin Oyate Territory and Treaty Boundaries 1851-Present", \#StandingRockSyllabus, NYC Stands with Standing Rock Collective, 2016, https://nycstandswithstandingrock.wordpress.com/standingrocksyllabus/.

22 G.N. Uzoigwe, "Reflections on the Berlin West Africa Conference, 1884-1885", Journal of the Historical Society of Nigeria 12, nos 3 and 4 (December 1984-June 1985), 15.

23 Anthony Costello et al., "Managing the Health Effects of Climate Change, Lancet and the University College London Institute for Global Health Commission, Lancet 373, no. 9676 (2009), 1703. This map is reproduced and discussed in Nicholas Mirzoeff, "Visualizing the Anthropocene", Public Culture 26, no. 2 (2014): 226-227.

24 Heather Davis and Zoë Todd, "On the Importance of a Date, or Decolonizing the Anthropocene", ACME: An International Journal for Critical Geographies 16, no. 4 (2017), 763. On intersectionality, see Kimberlé Crenshaw, "Demarginalizing the Intersection of Race and Sex: A Black Feminist Critique of Antidiscrimination Doctrine, Feminist Theory, and Antiracist Politics", University of Chicago Legal Forum 140 (1989): 139-167; for its application to ecology, see T.J. Demos, "Ecology-as-Intrasectionality", Bully Pulpit, Panorama: Journal of the Association of Historians of American Art 5, no. 1 (Spring 2019), https://doi.org/10.24926/24716839.1699, and two panels Demos co-organized with Emily Eliza Scott, "Ecology as Intersectionality: Aesthetic Approaches to Social-Justice Environmentalism", College Art Association 107th Annual Conference, 13 February 2019; “Ecology-As Intrasectionality: Radicalizing Arts of Climate Justice", New York University, 14 February 2019.

25 I conducted this research with a permit from the Navajo Nation Historic Preservation Department as part of my bookin-progress, Earth Diplomacy: Indigenous American Art and Reciprocity, 1953-1973.

26 Fred Stevens, untitled document, 1966, 3. Horniman Museum Archives.

27 D.M. Boston, G.E. Williams, and G.W.P. Jarvis, "Conservation of a Navajo Sand-Painting”, (1968), 1. Horniman Museum and Gardens Archives.

28 Rob Wallace, "Agribusiness Kills: Capitalists Agriculture and COVID-19: A Deadly Combination", Climate and Capitalism (11 March 2020).

29 Andreas Malm, "Fossil Fascism and the Lessons for the Greens", Green European Journal, 26 March 2020).

30 Oil and Gas Pollution in Vaca Muerta, https://forensic-architecture.org/investigation/oil-and-gas-pollution-in-vacamuerta.

31 Mel Evans, Art Wash: Big Oil and the Arts (London: Pluto Press, 2015).

32 Richard Misrach and Kate Orff, Petrochemical America (New York: Aperture, 2014). Petrochemical America, https://www.scapestudio.com/projects/petrochemical-america-

book/\#: :text=Petrochemical\%20America\%20represents\%20a\%20unique,and\%20landscape\%20architect\%20Kate\%200rff.\&text=A\%20

33 See "Kwel' Hoy: We Draw the Line!", Carnegie Museum of Natural History, https://carnegiemnh.org/kwel-hoy-drawline/; and "Kwel' Hoy: Many Struggles, One Front", Watershed Institute, 10 April 2018, https://thewatershed.org/kwelhoy-2/.

34 Martín Arboleda, Planetary Mine: Territories of Extraction Under Late Capitalism (New York: Verso, 2020).

35 Theodor W. Adorno, Aesthetic Theory, translated by Robert Hullot-Kentor (London: Continuum, 1997).

36 Shadreck Chirikure, Metals in Past Societies: A Global Perspective on Indigenous African Metallurgy (Cham: Springer, 2015).

37 Roseline Yemisi Olobatoke and Manny Mathuthu, "Heavy Metal Concentration in Soil in the Tailing Dam Vicinity of an Old Gold Mine in Johannesburg, South Africa", Canadian Journal of Soil Science 96(3) (2016): 299-304.

38 Chirikure, Metals in Past Societies.

39 Shadreck Chirikure, "New Light on Njanja Iron Working: Towards a Systematic Encounter Between Ethnohistory and Archaeometallurgy", The South African Archaeological Bulletin 61, no. 184 (2006): 142-151.

40 Gabrielle Hecht, "Interscalar Vehicles for an African Anthropocene: On Waste, Temporality, and Violence", Cultural Anthropology 33, no. 1 (2018): 109-141.

41 See The Extractive Zone: Social Ecologies and Decolonial Perspectives (Durham, NC: Duke University Press, 2017) and At the Sea's Edge: After the Colonial Anthropocene (Durham, NC: Duke University Press, forthcoming). 
42 Ann Laura Stoler, Carnal Knowledge and Imperial Power: Race and the Intimate in Colonial Rule (Berkeley, CA: University of California Press, 2002).

43 The vessels of racial slavery became repurposed as the ships of racial indenture in a violent recycling of labour, an extraction of disposable, fungible life. Black and Asian subjects became racialized and treated as if they were renewable resources, mined from West Africa, mined from Kolkata, mined from Hong Kong. In order to discipline and differentiate these subjects, race was necessary. Taxonomy is an anxious fiction that requires repetition and societies like the Linnean to become true.

44 Kamau Brathwaite, Caribbean Man in Space and Time: A Bibliographical and Conceptual Approach (Mona: Savacou Publications, 1974).

45 Michelle Stephens, "Arc'd Relations: Archive and Archipelago in the Greater Caribbean", Relational Undercurrents: Contemporary Art of the Caribbean Archipelago (Durham, NC: Duke University Press, 2017), 278.

46 Consider, rather than believe Picasso gave Lam the license to examine his Blackness, perhaps Picasso's unabashed citational extraction of African iconography and masks was natural for a Spaniard. Lam's situation in the artistic school of Negritude in 1930s Paris makes the reading of his most famous work La Jungla (1943) clear. It sits on display at the Museum of Modern Art with a grid-like form that evinces the anthropomorphic violence, taxonomy, and otherworldliness of the sugarcane plantation.

47 Tao Leigh Goffe, “'Guano in their Destiny': Race, Geology, and a Philosophy of Indenture”, Amerasia Journal, June 2019.

48 Wilson Harris, "The Music of Living Landscapes" (1996), Selected Writings of Wilson Harris: The Unfinished Genesis of the Imagination, edited by Andrew Bundy (London: Routledge, 1999), 41.

49 Harris, "Continuity and Discontinuity", Selected Writings of Wilson Harris, 183.

50 Kathryn Yusoff, A Billion Black Anthropocenes or None (Minneapolis, MN: University of Minnesota Press, 2018).

51 Marion Ernwein, Franklin Ginn, and James Palmer (eds), The Work that Plants do: Life, Labour and the Futures of Vegetal Economies (Bielefeld: Transcript, 2021).

52 Claire Colebrook, The Death of the Posthuman: Essays on Extinction, Vol. 1 (London: Open Humanities Press, 2014), 119.

53 Nigel Clark, A. Gormally, and H. Tuffen, “Speculative Volcanology: Time, Becoming and Violence in Encounters with Magma", Environmental Humanities 10, no. 1 (2018): 273-294.

54 Alex Shashkevich, "On the Eve of the 150th Anniversary of the First Transcontinental Railroad, Whither the Gold Spike?, Stanford News, 7 May 2019, https://news.stanford.edu/thedish/2019/05/07/on-the-eve-of-the-150thanniversary-of-the-first-continental-railroad-whither-the-gold-spikel, accessed 20 October 2020; Walter Benjamin, "On the Concept of History", Selected Writings, Volume 4, 1938-1940, edited by Howard Eiland and Michael W. Jennings (Cambridge, MA: Harvard University Press, 2003), 391-392.

55 The Geological Society, "2019 at the Geological Society is the Themed Year of Carbon!”, https://www.geolsoc.org.uk/ About/Themed-Years/Year-of-Carbon, accessed 20 October 2020.

56 Valerie Pavilonis, "Swensen Breaks Silence on Divestment", Yale News, 21 February 2020, https://yaledailynews.com/ blog/2020/02/21/swensen-breaks-silence-on-divestment/, accessed 20 October 2020.

57 See Ruth Walker, "Interview: Polly Higgins, Lawyer and Campaigner", The Scotsman, 20 May 2012, https://www.scotsman.com/news/interview-polly-higgins-lawyer-and-campaigner-1626650, accessed 20 October 2020.

58 See Richard Heede, “Tracing Anthropogenic Carbon Dioxide and Methane Emissions to Fossil Fuel and Cement Producers, 1854-2010", Climatic Change 122 (2014): 229-241, DOI 10.1007/s10584-013-0986-y.

59 Andrea Gaynor and lan McLean, "Landscape Histories: Mapping Environmental and Ecological Change Through the Landscape Art of the Swan River Region of Western Australia", Environment and History 14, no. 2 (May 2008): 187-204, doi:10.3197/096734008X303728.

60 Sarah Whatmore, "Materialist Returns: Practising Cultural Geography in and for a More-Than-Human World", Cultural Geographies 13 (2006): 600-609.

61 Bernard Stiegler, The Neganthropocene, translated by Daniel Ross (London: Open Humanities Press, 2018),

62 Kyle P. Whyte, "Indigenous Science (Fiction) for the Anthropocene: Ancestral Dystopias and Fantasies of Climate Change Crisis", Environment and Planning E: Nature and Space 1 (2018): 224-242.

63 Davis and Todd counter scholarly timelines that locate the Anthropocene at the beginning of the Industrial Revolution, or the advent of the atom bomb, as many geologists have suggested; Heather Davis and Zoë Todd, "On the Importance of a Date, or Decolonizing the Anthropocene", ACME: An International Journal for Critical Geographies 16, no. 4 (2017): 761-780. Recent studies of the geological record have likewise suggested that 1610 is the "golden spike", or start of the climate crisis. Simon L. Lewis and Mark A. Maslin, "Defining the Anthropocene", Nature 519 (March 2015): 171-180, doi:10.1038/nature14258.

64 Macarena Gómez-Barris, The Extractive Zone: Social Ecologies and Decolonial Perspectives (Durham, NC: Duke University Press, 2017), 5.

65 Davis and Todd, "On the Importance of a Date, or Decolonizing the Anthropocene", 767.

66 John Ruskin, The Storm Cloud of the Nineteenth Century (London: G. Allen, 1884). 
67 Mahader Tamene, Elleni M. Hailu, Rachel L. Berkowitz, and Xing Gao, “Why Black, Indigenous and Other People of Color Experience Greater Harm During the Pandemic", Smithsonian Magazine, 12 September 2020, https://www.smithsonianmag.com/smithsonian-institution/why-blacks-indigenous-and-other-people-color-experiencegreater-harm-during-pandemic-180975773/.

68 The work is an extension of Willard's collaborative project BUSH Gallery, a "Conceptual and Experimental Indigenous Led Land-Based Artist Rez-Idency", see http://www.bushgallery.ca; and https://www.taniawillard.ca/gallery/bushgallery.

69 Tania Willard, “Strong Breeze: Cmes'ekst", in Christine Shaw and Etienne Turpin (eds), The Work of Wind: Land (Berlin: K. Verlag, 2018), 190.

70 Gómez-Barris coined the term "fish-eye episteme", which involves a cognitive shift to viewpoints beyond the typical limits of human perception.

71 Zoë Todd, "Refracting the State Through Human-Fish Relations: Fishing, Indigenous Legal Orders and Colonialism in North/Western Canada", Decolonization: Indigeneity, Education \& Society 7, no. 1 (2018), 64.

72 See Anna Loewenhaupt Tsing, The Mushroom at the End of the World: On the Possibility of Life in Capitalist Ruins (Princeton, NJ: Princeton University Press, 2015), 152.

73 Stewart Sillars, Painting Shakespeare: The Artist as Critic, 1720-1820 (Baltimore, MD: Johns Hopkins University Press, 2006), 91.

74 Astrida Neimanis and Jennifer Hamilton, "Weathering", Feminist Review 118, no. 1 (2018), 81.

75 Astrida Neimanis and Rachel Loewen Walker, “Weathering: Climate Change and the 'Thick Time' of Transcorporeality", Hypatia 29, no. 3 (2014): 558-575.

$\underline{76}$ Neimanis and Hamilton, "Weathering", 80-84.

77 For intermittent updates on the collective's sporadic activities, see www.weatheringstation.net.

78 The "blame" for the bad transition is usually placed at the feet of his evil daughters. For an alternative reading which is more focused on Lear's role, please see Jennifer Mae Hamilton, “Cataclysmic Shame: Three Views of Lear's Mortal Body in the Storm", in This Contentious Storm: An Ecocritical and Performance History of King Lear (London: Bloomsbury Academic, 2017), 65-108.

79 Latour suggested this critique more generally in Bruno Latour, "Why has Critique run out of Steam: From Matters of Fact to Matters of Concern", Critical Inquiry 30, no. 2 (2004): 225-248.

80 Claire Bishop, Artificial Hells: Participatory Art and the Politics of Spectatorship (London: Verso, 2012), 283.

81 George Perkins Marsh, Man and Nature, Seattle, WA: University of Washington Press, 2003 [1864]), 464.

82 Marsh, Man and Nature, 464.

83 John Ruskin, Modern Painters V (1860), in The Works of John Ruskin, edited by E.T. Cook and Alexander Wedderburn (London: G. Allen, 1903-1912), Vol. 7, 452.

84 See Amy M. King, The Divine in the Commonplace: Reverent Natural History and the Novel in Britain (Cambridge: Cambridge University Press, 2019).

85 Henry David Thoreau, "9th May 1858”, The Journal: 1837-1861 (New York: New York Review of Books, 2009 ), 495.

86 Jesse Oak Taylor, The Sky of Our Manufacture: The London Fog in British Fiction from Dickens to Woolf (Charlottesville, VA: University of Virginia Press, 2016), 170.

87 Derek Walcott and Peter Doig, "Grande Riviere I", Morning, Paramin (New York: Farrar, Straus and Giroux, 2016 ), 49.

88 Walcott and Doig, "Grande Riviere I", 49.

89 Paul J. Crutzen, "Geology of Mankind", Nature 415 (3 January 2002), 23.

90 Jean Copains and Jean Jamin (eds), Aux origines de l'anthropologie française (Paris: Éditions Jean-Michel Place, 1994).

91 Miranda Hughes, "The Dynamometer and the Diemenese", in Homer Le Grand (ed.), Experimental Inquiries (Dordrecht: Kluwer, 1990), 81-98.

92 Ingereth Macfarlane and Mark Hannah (eds), Transgressions: Critical Australian Indigenous Histories (Canberra: Australian National University Press, 2007).

93 Jacques Payen, Capital et machine à vapeur au 18e siècle (Paris: Mouton \& Co., 1969).

94 Andreas Malm, "Who Lit this Fire? Approaching the History of the Fossil Economy", Critical Historical Studies 3, no. 2 (Fall 2016): 215-248.

95 Bronwen Douglas, Science, Voyages and Encounters in Oceania 1511-1850 (London: Palgrave Macmillan, 2014).

96 Joseph Fourier, Discours prononcés dans la séance publique tenue par l'Académie Française (Paris: Firmin Didot, 1827).

97 Maurits W. Ertsen, “Colonial Irrigation: Myths of Emptiness”, Landscape Research 31, no. 2 (2006), 147-167. 


\section{Licensing}

The Publishers of British Art Studies are committed to supporting scholarship on British art and architecture of all periods. This publication is made available free of charge at https://www.britishartstudies.ac.uk. We ask users to identify the use of materials made available through this website and to provide an appropriate credit to the to the author and the publication, so that others may find and use our resources.

Except where otherwise noted, this work is licensed under a Creative Commons Attribution-NonCommercial 2.0 UK: England \& Wales Licence (CC BY-NC 2.0 UK). To view a copy of this license, visit https://creativecommons.org/licenses/by-nc/2.0/uk/ or send a letter to Creative Commons, PO Box 1866, Mountain View, CA 94042, USA.

The Publishers fully support the protection of intellectual property and are committed to complying with, and strictly adhering to, all applicable copyright law. In many cases, copyright or other proprietary rights may be held by individuals or entities other than, or in addition to, the Publishers. If a work or a photographic image is still protected by copyright, you must cite the relevant copyright information when using the image and comply with all other terms or restrictions that may be applicable to that material.

In some cases, exceptions to copyright that permit limited use of protected works without the permission of the copyright owner may have be applied. We are confident that we have carried out due diligence in our use of copyrighted material as required, but we apologise for any inadvertent infringement of rights.

Digital copies of resources are made accessible for research for one of the following reasons:

- they are in the public domain;

- the rights are owned by the Publishers;

- we make them accessible under an exception or limitation to UK copyright law, as outlined in the Copyright, Designs and Patents Act 1988 (as amended);

- we have permission to make them accessible;

- or, there are no known restrictions on use.

If you believe that we have made a mistake and wish for your material to be removed from our site, please contact us at copyright@paul-mellon-centre.ac.uk.

Please include the following information with your request:

- Name and contact information, including email address and phone number.

- Identification of the resource for consideration of removal. Providing URLs in your communication will help us locate content quickly.

- The reason for the request.

The Publishers respond promptly, normally within 21 business days. We may remove the resource from our site while we assess the validity of the request. Upon completion of the assessment, we will take appropriate action and communicate that action to you. 